\title{
Review \\ Precision Oncology via NMR-Based Metabolomics: A Review on Breast Cancer
}

\author{
Alessia Vignoli $\left.{ }^{1,2,+}{ }^{(}\right)$, Emanuela Risi ${ }^{3,+}{ }^{,}$Amelia McCartney ${ }^{3,4}{ }^{\circledR}$, Ilenia Migliaccio ${ }^{3}$, Erica Moretti ${ }^{3}$, \\ Luca Malorni $^{3}{ }^{(-)}$, Claudio Luchinat ${ }^{1,2,5, *}$, Laura Biganzoli ${ }^{3, \neq(1)}$ and Leonardo Tenori ${ }^{1,2,5, \neq(\mathbb{D}}$ \\ 1 Magnetic Resonance Center (CERM), University of Florence, 50019 Sesto Fiorentino, Italy; \\ vignoli@cerm.unifi.it (A.V.); tenori@cerm.unifi.it (L.T.) \\ 2 Department of Chemistry "Ugo Schiff", University of Florence, 50019 Sesto Fiorentino, Italy \\ 3 Department of Medical Oncology, New Hospital of Prato S. Stefano, 59100 Prato, Italy; \\ emanuela.risi@uslcentro.toscana.it (E.R.); amelia.mccartney@uslcentro.toscana.it (A.M.); \\ ilenia.migliaccio@uslcentro.toscana.it (I.M.); erica.moretti@uslcentro.toscana.it (E.M.); \\ luca.malorni@uslcentro.toscana.it (L.M.); laura.biganzoli@uslcentro.toscana.it (L.B.) \\ 4 School of Clinical Sciences, Monash University, Melbourne 3800, Australia \\ 5 Consorzio Interuniversitario Risonanze Magnetiche di Metallo Proteine (C.I.R.M.M.P.), \\ 50019 Sesto Fiorentino, Italy \\ * Correspondence: claudioluchinat@cerm.unifi.it; Tel.: +39-055-457-4296 \\ + Co-first authors. \\ $\ddagger$ Co-last authors.
}

Citation: Vignoli, A.; Risi, E.;

McCartney, A.; Migliaccio, I.; Moretti,

E.; Malorni, L.; Luchinat, C.;

Biganzoli, L.; Tenori, L. Precision

Oncology via NMR-Based

Metabolomics: A Review on Breast

Cancer. Int. J. Mol. Sci. 2021, 22, 4687.

https://doi.org/10.3390/ijms22094687

Academic Editor: Maurizio Callari

Received: 8 April 2021

Accepted: 27 April 2021

Published: 28 April 2021

Publisher's Note: MDPI stays neutral with regard to jurisdictional claims in published maps and institutional affiliations.

Copyright: (c) 2021 by the authors. Licensee MDPI, Basel, Switzerland. This article is an open access article distributed under the terms and conditions of the Creative Commons Attribution (CC BY) license (https:/ / creativecommons.org/licenses/by/ $4.0 /)$.

\begin{abstract}
Precision oncology is an emerging approach in cancer care. It aims at selecting the optimal therapy for the right patient by considering each patient's unique disease and individual health status. In the last years, it has become evident that breast cancer is an extremely heterogeneous disease, and therefore, patients need to be appropriately stratified to maximize survival and quality of life. Gene-expression tools have already positively assisted clinical decision making by estimating the risk of recurrence and the potential benefit from adjuvant chemotherapy. However, these approaches need refinement to further reduce the proportion of patients potentially exposed to unnecessary chemotherapy. Nuclear magnetic resonance (NMR) metabolomics has demonstrated to be an optimal approach for cancer research and has provided significant results in BC, in particular for prognostic and stratification purposes. In this review, we give an update on the status of NMR-based metabolomic studies for the biochemical characterization and stratification of breast cancer patients using different biospecimens (breast tissue, blood serum/plasma, and urine).
\end{abstract}

Keywords: metabolomics; NMR; breast cancer; precision medicine; chemotherapy

\section{Breast Cancer: Why Precision Oncology?}

Precision medicine, also called personalized medicine, is an emerging approach for disease treatment and prevention that takes into account genetics, epigenetics, metabolism, environment, and lifestyle of each individual person with the goal to select the optimal therapy for the right patient. In oncology, tumor molecular profiling leads to the identification of patient specific alterations that could inform about the optimal treatments and maximize patient's survival.

For several years breast cancer (BC) has been seen as a single clinical entity and treated with one general approach. However, now it has become extremely clear that $\mathrm{BC}$ has to be considered a highly heterogeneous disease with different subclasses. The discovery of endocrine receptors, and the understanding that endocrine therapy significantly improves outcomes in patients with hormone receptor-positive disease, marks the beginning of the target therapy for patients with BC [1-3]. By the late 1990s, it was discovered that a subgroup of breast tumors (15-20\%) overexpresses the HER2 receptor or have HER2 gene amplification. HER2-positive disease had a dismal outcome until the development of 
targeted agents, which has significantly improved outcomes in both the (neo)adjuvant [4-8] and the metastatic setting $[9,10]$. The more recent gene-expression assays allow clinicians to assess the risk of recurrence in early breast cancer (EBC) [11-13], as well as to predict potential benefit from adjuvant chemotherapy [14-17]. In many patients found to have a disease with favorable gene-expression profile, chemotherapy could be avoided; however, a significant population of EBC patients may still be overtreated. Precision oncology aims at identifying the optimal treatment for each patient, specifically tailored to each unique cancer profile and to each individual health status in order to maximize survival and quality of life. Omics sciences are instrumental for this aim (Figure 1).

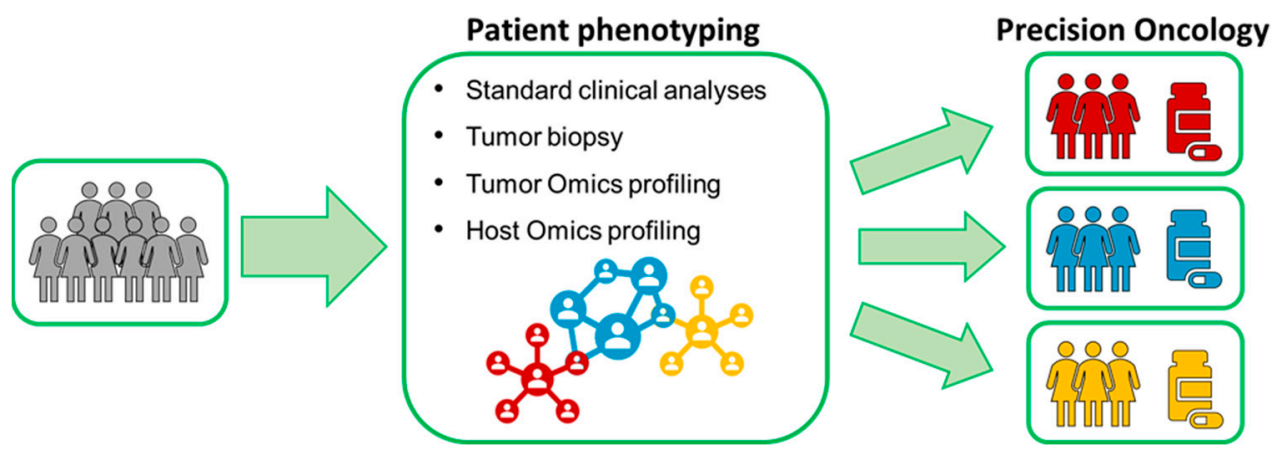

Figure 1. Precision oncology in a nutshell.

\section{Metabolomics and NMR}

Metabolomics, one of the latest-Omic sciences, entails the comprehensive characterization of the ensemble of endogenous and exogenous metabolites presents in a biological specimen. Metabolites simultaneously represent the downstream output of the genome, the transcriptome, and the proteome, as well as the upstream input from various external factors such as environment, lifestyle, diet, and drug exposure [18]. As a consequence, in the last few years, metabolomic phenotyping has been extensively applied in biomedical research.

Nuclear Magnetic Resonance spectroscopy (NMR) and mass spectrometry are the two most widely used analytical platforms for metabolomics. These two techniques can be considered complementary, since the weaknesses of one platform are compensated by the strengths of the other [19]. In contrast to the approach typically adopted in mass spectrometry, which is focused on target metabolites of interest, NMR metabolomics is usually performed using a high-throughput, untargeted approach, which provides a complete picture of all metabolites present or quantifiable in the sample above the NMR detection limit (concentrations $>1 \mu \mathrm{M}$ ) $[19,20]$. To date, NMR metabolomics are increasingly used for successful patient stratification in various diseases, and it provided unique insights into the fundamental causes of several physiological and pathophysiological conditions [21-35].

In principle, any biospecimen (i.e., cells, biofluids, and tissues) can be analyzed via NMR. The most common biological fluids analyzed by metabolomics are blood serum/ plasma, urine, and saliva, as they can be collected with low invasiveness, and yield plentiful in biological information. Blood derivatives contain all the molecules that are secreted by different tissues in response to different physiological stimuli, conditions, or stressors [36]. Due to its important systemic role, the concentrations of metabolites in the blood are strongly controlled by feedback cycles, so serum/plasma samples are not subjected to extreme daily variations and can give information at a systemic level. Conversely, urine essentially contains metabolic waste, and thus is more affected by diet, environment lifestyle, and drug administration, resulting in significant day-to-day variability [37]. Saliva is an important physiological fluid that contains a highly complex mixture of substances, and it reflects both the systemic status [38] and the local health condition of the oral cavity [39]. A number of other local biofluids, such as exhaled breath condensate [40-42], cerebrospinal fluid [43,44], amniotic fluid [45], bile [46], synovial fluid [47,48], seminal fluid [49], and fecal extracts [50] can also be analyzed to investigate the metabolome of 
specific compartments. Cell lysates, cell growth media, and extracts of tissues can also be analyzed [51,52]. Further, the development of high resolution (HR) ${ }^{1} \mathrm{H}$ magic angle spinning (MAS) spectra [53] has made viable the acquisition of data on small slices of tissue without the need of any extraction or pre-treatment [54-56].

Metabolomic fingerprints, as well as the identification and quantification of the most abundant metabolites (metabolomic profiling), can be directly obtained by the analysis of basic one-dimensional (1D) NMR spectra. ${ }^{1}$ D NOESY [57], ${ }^{1}$ H CPMG (Carr-PurcellMeiboom-Gill) [58], and ${ }^{1} \mathrm{H}$ diffusion-edited [59] are the pulse sequences most commonly used in metabolomics studies. NOESY spectra enables the detection of all molecules present in the sample above the NMR detection limit, CPMG spectra allow the selective detection of low molecular weight metabolites, whereas diffusion-edited spectra permit the observation of only high-molecular weight macromolecules (i.e., proteins and lipoproteins). The latter two sequences are particularly useful in biofluids such as serum/plasma that contain high amounts of both low and high molecular weight compounds.

Limiting the analysis to the most common biofluids employed in metabolomics, the number of molecules detectable and quantifiable by 1D-NMR span from slightly more than ten in breath condensate, to more than one hundred in urine. Assignment is mostly based on literature data, public databases, such as the de-facto reference standard Human Metabolome Database (HMDB) [60-62], commercially available databases and profiling software (i.e., ChenomX, AssureNMR). Spectra acquired at high magnetic field and twodimensional experiments can be non-routinely employed in selected samples to identify unknown metabolites or to confirm NMR assignment [63]. Remarkably, besides small metabolites, serum and plasma also contain lipoproteins that with appropriate software (i.e., the Bruker IVDr platform) can be finely analyzed to derive, from serum and plasma NMR spectra, about 100 different lipid parameters that describe the distribution and analytical composition of lipid main fractions and subclasses [64]. This is especially important in the lipidomics domain, because the composition of lipoproteins has a strong influence on disease development, including BC [65].

If applied for population screening, NMR-based metabolomics/lipidomics could become a powerful clinical tool in precision oncology. However, to permit experimental reproducibility among different studies and/or different collection centers, it is extremely important that metabolomic data are collected under rigorously controlled standard operating procedures (SOPs). SOPs need to be strictly followed in all the main steps involved in the metabolomic work-flow, including sample collection, preanalytical processing, and storage [66-68]; NMR spectra recording [69]; and data/metadata compilation, description and storage [70].

In this review, we will present an overview on the current status of NMR-based metabolomics studies in the setting of breast cancer using three different biological samples: breast tissue, serum/plasma and urine (Figure 2, Table 1). The translation in the clinical practice and the future perspectives for this analytical approach will be also examined and discussed.

The scientific publications reviewed in the present article were identified by database searching in three electronic databases [National Library of Medicine (Medline via PubMed ${ }^{\circledR}$ ), Web of Science and Scopus] without any restriction on date of publication or publication status. Keywords were used as follows: ("metabolomics" OR "metabonomics) AND ("NMR" OR "nuclear magnetic resonance spectroscopy") AND ("breast cancer") AND ("biospecimen", where biospecimen is tissue or plasma or serum or urine). The results of the searches were manually refined in order to remove non pertinent articles. In addition, previous systematic reviews were checked to ensure complete data collection. 
Table 1. List of evaluated publications.

\begin{tabular}{|c|c|c|c|c|c|c|c|c|}
\hline Ref. & Biospecimen & Population Study (n) & Cohort Allocation & EBC/MBC & ER Status & HER2 Status & Mean Age (Yrs) & NMR (MHz) \\
\hline $\begin{array}{l}\text { Borgan et al., } \\
2010[71]\end{array}$ & $\mathrm{T}$ & $46 \mathrm{BC}$ & $\begin{array}{l}\text { Trondheim } \\
\text { (Norway) }\end{array}$ & $46 \mathrm{EBC}$ & $41 \mathrm{ER}+/ 5 \mathrm{ER}-$ & Not reported & 64 & 600 \\
\hline $\begin{array}{c}\text { Li et al., } 2011 \\
\text { [72] }\end{array}$ & $\mathrm{T}$ & 31 (13 BC; $18 \mathrm{HC})$ & Seoul (South Korea) & 13 EBC (11 IC; 2 DCIS) & $11 \mathrm{ER}+/ 2 \mathrm{ER}-$ & $\begin{array}{c}12 \text { HER2+ / } 1 \\
\text { HER2 }\end{array}$ & 50 & 500 \\
\hline $\begin{array}{l}\text { Bathen et al., } \\
2013 \text { [73] }\end{array}$ & $\mathrm{T}$ & $228 \mathrm{BC}$ & $\begin{array}{l}\text { Trondheim } \\
\text { (Norway) }\end{array}$ & $228 \mathrm{EBC}$ & $168 \mathrm{ER}+/ 49 \mathrm{ER}-$ & Not reported & 60.7 & 600 \\
\hline $\begin{array}{c}\text { Chae et al., } 2016 \\
\text { [74] }\end{array}$ & $\mathrm{T}$ & $60 \mathrm{BC}$ & Seoul (South Korea) & $\begin{array}{c}60 \text { EBC (30 DCIS; } 30 \\
\text { DCIS + IC) }\end{array}$ & $40 \mathrm{ER}+/ 20 \mathrm{ER}-$ & $\begin{array}{c}4 \text { HER2+/36 } \\
\text { HER2- }\end{array}$ & 48.7 & 400 \\
\hline $\begin{array}{c}\text { Park et al., } 2016 \\
\text { [75] }\end{array}$ & $\mathrm{T}$ & $31 \mathrm{BC}$ & Seoul (South Korea) & 31 EBC (IC) & $21 \mathrm{ER+/10} \mathrm{ER-}$ & $\begin{array}{c}23 \text { HER2+/8 } \\
\text { HER2- }\end{array}$ & 54.2 & 600 \\
\hline $\begin{array}{c}\text { Gogiashvili } \\
\text { et al., } 2018 \text { [76] }\end{array}$ & $\mathrm{T}$ & $18 \mathrm{BC}$ & $\begin{array}{l}\text { Oberhavel } \\
\text { (Germany) }\end{array}$ & $18 \mathrm{EBC}$ & Not reported & Not reported & Not reported & 600 \\
\hline $\begin{array}{l}\text { Giskeødegård } \\
\text { et al., } 2010 \text { [77] }\end{array}$ & $\mathrm{T}$ & $160 \mathrm{BC}$ & $\begin{array}{c}\text { Trondheim } \\
\text { (Norway) }\end{array}$ & $160 \mathrm{EBC}(\mathrm{IC})$ & $119 \mathrm{ER}+/ 39 \mathrm{ER}-$ & Not reported & 62 & 600 \\
\hline $\begin{array}{c}\text { Choi et al., } 2012 \\
\text { [78] }\end{array}$ & $\mathrm{T}$ & $34 \mathrm{BC}$ & Seoul (South Korea) & $34 \mathrm{EBC}$ (IC) & $26 \mathrm{ER}+/ 6 \mathrm{ER}-$ & $\begin{array}{c}5 \text { HER2+ } / 27 \\
\text { HER2- }\end{array}$ & 52.2 & 500 \\
\hline $\begin{array}{c}\text { Cao et al., } 2014 \\
\text { [79] }\end{array}$ & $\mathrm{T}$ & $75 \mathrm{BC}$ & $\begin{array}{l}\text { Trondheim } \\
\text { (Norway) }\end{array}$ & 75 EBC (IC) & $44 \mathrm{ER+/31} \mathrm{ER-}$ & $\begin{array}{c}30 \text { HER2+ / } 45 \\
\text { HER2- }\end{array}$ & 64 & 600 \\
\hline $\begin{array}{c}\text { Tayyari et al., } \\
2018 \text { [80] }\end{array}$ & $\mathrm{T}$ & $82(47 \mathrm{BC} ; 35 \mathrm{HC})$ & Multicenters USA & 47 EBC (44 IC; 3 DCIS) & $29 \mathrm{ER}+/ 18 \mathrm{ER}-$ & $\begin{array}{l}47 \text { HER2+ / } 0 \\
\text { HER2- }\end{array}$ & Not reported & 800 \\
\hline $\begin{array}{c}\text { Cheng et al., } \\
1998 \text { [81] }\end{array}$ & $\mathrm{T}$ & $19 \mathrm{BC}$ & Boston (USA) & 19 EBC (18 IC;1 DCIS) & Not reported & Not reported & 60 & 400 \\
\hline $\begin{array}{l}\text { Bathen et al., } \\
2007 \text { [82] }\end{array}$ & $\mathrm{T}$ & $77 \mathrm{BC}$ & $\begin{array}{l}\text { Trondheim } \\
\text { (Norway) }\end{array}$ & 77 EBC (IC) & $62 \mathrm{ER}+/ 15 \mathrm{ER}-$ & Not reported & 62 & 600 \\
\hline $\begin{array}{c}\text { Sitter et al., } 2006 \\
\text { [83] }\end{array}$ & $\mathrm{T}$ & 85 (83 BC, 1 LC, 1 HC) & $\begin{array}{l}\text { Trondheim } \\
\text { (Norway) }\end{array}$ & $83 \mathrm{EBC}$ & Not reported & Not reported & 62 & 600 \\
\hline $\begin{array}{c}\text { Sitter et al., } 2010 \\
\text { [84] }\end{array}$ & $\mathrm{T}$ & $29 \mathrm{BC}$ & $\begin{array}{l}\text { Trondheim } \\
\text { (Norway) }\end{array}$ & $29 \mathrm{EBC}(\mathrm{IC})$ & $18 \mathrm{ER}+/ 11 \mathrm{ER}-$ & Not reported & Not reported & 600 \\
\hline $\begin{array}{c}\text { Choi et al., } 2013 \\
\text { [85] }\end{array}$ & $\mathrm{T}$ & $37 \mathrm{BC}$ & Seoul (South Korea) & & $25 \mathrm{ER}+/ 12 \mathrm{ER}-$ & $\begin{array}{c}14 \text { HER2+ / } 25 \\
\text { HER2- }\end{array}$ & 50.5 & 500 \\
\hline
\end{tabular}


Table 1. Cont

\begin{tabular}{|c|c|c|c|c|c|c|c|c|}
\hline Ref. & Biospecimen & Population Study (n) & Cohort Allocation & EBC/MBC & ER Status & HER2 Status & Mean Age (Yrs) & NMR (MHz) \\
\hline $\begin{array}{c}\text { Euceda et al., } \\
2017 \text { [86] }\end{array}$ & $\mathrm{T}$ & $122 \mathrm{BC}$ & $\begin{array}{l}\text { Trondheim } \\
\text { (Norway) }\end{array}$ & $122 \mathrm{EBC}(\mathrm{IC})$ & $101 \mathrm{ER}+/ 21 \mathrm{ER}-$ & 122 HER2- & 49 & 600 \\
\hline $\begin{array}{c}\text { Cao et al., } 2012 \\
\text { [87] }\end{array}$ & $\mathrm{T}$ & $30 \mathrm{BC}$ & $\begin{array}{l}\text { Trondheim } \\
\text { (Norway) }\end{array}$ & $30 \mathrm{EBC}(\mathrm{IC})$ & $27 \mathrm{ER}+/ 3 \mathrm{ER}-$ & Not reported & 62 & 600 \\
\hline $\begin{array}{l}\text { Giskeødegård } \\
\text { et al., } 2012 \text { [88] }\end{array}$ & $\mathrm{T}$ & $98 \mathrm{BC}$ & $\begin{array}{l}\text { Trondheim } \\
\text { (Norway) }\end{array}$ & $98 \mathrm{EBC}(\mathrm{IC})$ & $71 \mathrm{ER}+/ 24 \mathrm{ER}-$ & Not reported & 69 & 600 \\
\hline $\begin{array}{c}\text { Cao et al., } 2012 \\
\text { [89] }\end{array}$ & $\mathrm{T}$ & $85 \mathrm{BC}$ & $\begin{array}{l}\text { Trondheim } \\
\text { (Norway) }\end{array}$ & $80 \mathrm{EBC}, 5 \mathrm{MBC}$ (IC) & $50 \mathrm{ER}+/ 34 \mathrm{ER}-$ & Not reported & 49 & 600 \\
\hline $\begin{array}{c}\text { Haukaas et al., } \\
2016 \text { [90] }\end{array}$ & $\mathrm{T}$ & $228 \mathrm{BC}$ & $\begin{array}{c}\text { Oslo } \\
\text { (Norway) }\end{array}$ & $\begin{array}{c}228 \text { EBC (224 IC; } 4 \\
\text { DCIS) }\end{array}$ & $178 \mathrm{ER}+/ 40 \mathrm{ER}-$ & $\begin{array}{c}26 \text { HER2 + /192 } \\
\text { HER2- }\end{array}$ & 55.5 & 600 \\
\hline $\begin{array}{c}\text { Yoon et al., } 2016 \\
\text { [91] }\end{array}$ & $\mathrm{T}$ & $53 \mathrm{BC}$ & Seoul (South Korea) & 53 EBC (IC) & $36 \mathrm{ER}+/ 17 \mathrm{ER}-$ & $\begin{array}{c}12 \text { HER2+/41 } \\
\text { HER2- }\end{array}$ & 49.6 & 600 \\
\hline $\begin{array}{c}\text { Debik et al., } 2019 \\
\text { [92] }\end{array}$ & $\mathrm{T}, \mathrm{S}$ & $118 \mathrm{BC}$ & Oslo (Norway) & $118 \mathrm{EBC}(\mathrm{IC})$ & $100 \mathrm{ER}+/ 18 \mathrm{ER}-$ & 118 HER2- & 48.9 & 600 \\
\hline $\begin{array}{c}\text { Bro et al., } 2015 \\
{[93]}\end{array}$ & $\mathrm{P}$ & 838 (419 BC; 419 HC) & Denmark & not reported & not reported & not reported & not reported & 600 \\
\hline $\begin{array}{c}\text { Cala et al., } 2018 \\
\text { [94] }\end{array}$ & $\mathrm{P}$ & $58(29 \mathrm{BC} ; 29 \mathrm{HC})$ & Bogotà (Colombia) & $\begin{array}{c}29 \text { EBC (19 IDC; } 10 \\
\text { ILC) }\end{array}$ & $19 \mathrm{ER}+/ 10 \mathrm{ER}-$ & $\begin{array}{c}6 \text { HER2+ } / 23 \\
\text { HER2- }\end{array}$ & 51 & 400 \\
\hline $\begin{array}{c}\text { Lecuyer et al., } \\
2018 \text { [95] }\end{array}$ & $\mathrm{P}$ & 602 (206 BC; 396 HC) & France & not reported & not reported & not reported & 49.3 & 500 \\
\hline $\begin{array}{c}\text { Louis et al., } 2015 \\
\text { [96] }\end{array}$ & $\mathrm{P}$ & 145 (73 BC; $72 \mathrm{HC})$ & Hasselt (Belgium) & $\begin{array}{l}73 \text { EBC (61 IDC; } 11 \\
\text { ILC; } 1 \text { DCIS) }\end{array}$ & $62 \mathrm{ER}+/ 11 \mathrm{ER}-$ & not reported & 58.5 & 400 \\
\hline $\begin{array}{c}\text { Richard et al., } \\
2017 \text { [97] }\end{array}$ & $\mathrm{P}$ & $65 \mathrm{BC}$ & Mons (Belgium) & 50 EBC (IC); $15 \mathrm{MBC}$ & not reported & not reported & 57.6 & 500 \\
\hline $\begin{array}{l}\text { Suman et al., } \\
2018 \text { [98] }\end{array}$ & $\mathrm{P}$ & $122(72 \mathrm{BC} ; 50 \mathrm{HC})$ & Lucknow (India) & not reported & not reported & not reported & 44.3 & 800 \\
\hline $\begin{array}{l}\text { Vignoli et al., } \\
2020 \text { [99] }\end{array}$ & $\mathrm{P}$ & $43 \mathrm{BC}$ & Aviano (Italy) & 43 EBC (IC) & $22 \mathrm{ER}+/ 21 \mathrm{ER}-$ & 43 HER2+ & 49 & 600 \\
\hline $\begin{array}{l}\text { Jobard et al., } \\
2021 \text { [100] }\end{array}$ & $\mathrm{P}$ & 1582 (791 BC; 791 HC) & Lyon (France) & $\begin{array}{c}791 \text { EBC (685 IC; } 69 \\
\text { DCIS) }\end{array}$ & $\begin{array}{c}\text { EBC: } 536 \text { ER+/100 } \\
\text { ER }-\end{array}$ & Not reported & 56.8 & 600 \\
\hline
\end{tabular}


Table 1. Cont.

\begin{tabular}{|c|c|c|c|c|c|c|c|c|}
\hline Ref. & Biospecimen & Population Study $(n)$ & Cohort Allocation & EBC/MBC & ER Status & HER2 Status & Mean Age (Yrs) & NMR (MHz) \\
\hline Keun et al. [101] & $\mathrm{S}$ & $21 \mathrm{BC}$ & London (England) & Not reported & Not reported & Not reported & 59 & 600 \\
\hline $\begin{array}{c}\text { Asiago et al., } \\
\text { [102] } 2010\end{array}$ & $\mathrm{~S}$ & $56 \mathrm{BC}$ & Houston (TX, USA) & 56 EBC (IC) & $26 \mathrm{ER}+/ 25 \mathrm{ER}-$ & not reported & 53.7 & 500 \\
\hline $\begin{array}{c}\text { Gu et al., } 2011 \\
{[103]}\end{array}$ & $\mathrm{S}$ & $57(27 \mathrm{BC} ; 30 \mathrm{HC})$ & Detroit (MI, USA) & not reported & not reported & not reported & 55.9 & 500 \\
\hline $\begin{array}{c}\text { Stebbing et al., } \\
2012 \text { [104] }\end{array}$ & $\mathrm{S}$ & $88 \mathrm{BC}$ & London (England) & $13 \mathrm{EBC} ; 75 \mathrm{MBC}$ & $64 \mathrm{ER}+/ 24 \mathrm{ER}-$ & $\begin{array}{c}34 \text { HER2+/54 } \\
\text { HER2- }\end{array}$ & 59 & 600 \\
\hline $\begin{array}{c}\text { Hart et al., } 2017 \\
\text { [105] }\end{array}$ & $\mathrm{S}$ & 699 BC & International & $\begin{array}{c}590 \text { EBC (IC); } 109 \\
\text { MBC }\end{array}$ & $\begin{array}{c}\text { EBC: } 552 \mathrm{ER}+/ 37 \\
\text { ER }-\end{array}$ & $\begin{array}{c}\text { EBC: } 108 \\
\text { HER2+/388 } \\
\text { HER2- }\end{array}$ & 41.5 & 600 \\
\hline $\begin{array}{c}\text { Jiang et al., } 2018 \\
\text { [106] }\end{array}$ & $\mathrm{S}$ & $29 \mathrm{BC}$ & Singapore & $29 \mathrm{MBC}$ & not reported & $\begin{array}{c}6 \text { HER2+ } / 7 \\
\text { HER2- }\end{array}$ & 52.7 & 800 \\
\hline $\begin{array}{l}\text { Jobard et al., } \\
2017 \text { [107] }\end{array}$ & $\mathrm{S}$ & $79 \mathrm{BC}$ & France & $79 \mathrm{BC}$ & not reported & 79 HER2+ & 50.5 & 800 \\
\hline $\begin{array}{l}\text { Jobard et al., } \\
2014 \text { [108] }\end{array}$ & $\mathrm{S}$ & $190 \mathrm{BC}$ & Lyon (France) & $104 \mathrm{EBC} ; 86 \mathrm{MBC}$ & not reported & $\begin{array}{c}32 \text { HER2+ / } 156 \\
\text { HER2- }\end{array}$ & 57.1 & 800 \\
\hline $\begin{array}{c}\text { McCartney et al., } \\
2019 \text { [109] }\end{array}$ & $\mathrm{S}$ & $115 \mathrm{BC}$ & New York (USA) & $28 \mathrm{MBC} ; 87 \mathrm{EBC}(\mathrm{IC})$ & $115 \mathrm{ER}+$ & 115 HER2- & 54 & 600 \\
\hline $\begin{array}{l}\text { Oakman et al., } \\
2011 \text { [110] }\end{array}$ & $\mathrm{S}$ & $140 \mathrm{BC}$ & Prato (Italy) & 89 EBC (IC); $51 \mathrm{MBC}$ & $111 \mathrm{ER}+/ 29 \mathrm{ER}-$ & $\begin{array}{c}28 \text { HER2+/108 } \\
\text { HER2- }\end{array}$ & 57 & 600 \\
\hline $\begin{array}{c}\text { Singh et al., } 2017 \\
\text { [111] }\end{array}$ & $\mathrm{S}$ & $42(27 \mathrm{BC} ; 15 \mathrm{HC})$ & Lucknow (India) & 27 EBC (IC) & not reported & not reported & 58.6 & 800 \\
\hline $\begin{array}{l}\text { Tenori et al., } \\
2012 \text { [112] }\end{array}$ & $\mathrm{S}$ & $579 \mathrm{BC}$ & International & $579 \mathrm{MBC}$ & not reported & not reported & not reported & 600 \\
\hline $\begin{array}{c}\text { Tenori et al., } \\
2015 \text { [113] }\end{array}$ & $S$ & $175 \mathrm{BC}$ & New York (USA) & $95 \mathrm{MBC} ; 80 \mathrm{EBC}$ (IC) & $62 \mathrm{ER}+/ 110 \mathrm{ER}-$ & $\begin{array}{c}47 \text { HER2+/126 } \\
\text { HER2- }\end{array}$ & 53 & 600 \\
\hline $\begin{array}{c}\text { Wei et al., } 2013 \\
\text { [114] }\end{array}$ & $\mathrm{S}$ & $28 \mathrm{BC}$ & $\begin{array}{l}\text { Tübingen } \\
\text { (Germany) }\end{array}$ & $28 \mathrm{EBC}$ & $19 \mathrm{ER}+/ 9 \mathrm{ER}-$ & $\begin{array}{c}13 \text { HER2+/15 } \\
\text { HER2- }\end{array}$ & 47.9 & 600 \\
\hline $\begin{array}{l}\text { Wojtowicz et al., } \\
2020 \text { [115] }\end{array}$ & $\mathrm{S}$ & 95 (9 BC; $86 \mathrm{HC})$ & Wroclaw (Poland) & not reported & $9 \mathrm{ER}-$ & 9 HER2- & 56.67 & 600 \\
\hline
\end{tabular}


Table 1. Cont.

\begin{tabular}{|c|c|c|c|c|c|c|c|c|}
\hline Ref. & Biospecimen & Population Study $(n)$ & Cohort Allocation & EBC/MBC & ER Status & HER2 Status & Mean Age (Yrs) & NMR (MHz) \\
\hline $\begin{array}{c}\text { Flote et al., } 2016 \\
\text { [116] }\end{array}$ & $S$ & $56 \mathrm{BC}$ & Norway & 56 EBC (IC) & $52 \mathrm{ER}+/ 4 \mathrm{ER}-$ & $\begin{array}{c}3 \text { HER2+ } / 53 \\
\text { HER2 - }\end{array}$ & 55.1 & 600 \\
\hline $\begin{array}{l}\text { Madssen et al., } \\
2018 \text { [117] }\end{array}$ & $\mathrm{S}$ & $60 \mathrm{BC}$ & Norway & 56 EBC (4 DCIS; 56 IC) & $52 \mathrm{ER}+/ 4 \mathrm{ER}-$ & $\begin{array}{c}3 \text { HER2+/53 } \\
\text { HER2- }\end{array}$ & 55.4 & 600 \\
\hline $\begin{array}{c}\text { Zhou et al., } 2017 \\
\text { [118] }\end{array}$ & $\mathrm{S} ; \mathrm{U}$ & $22(11 \mathrm{BC} ; 11 \mathrm{HC})$ & Xi'an (China) & $10 \mathrm{EBC}(\mathrm{IC}) ; 1 \mathrm{MBC}$ & not reported & not reported & 58 & 600 \\
\hline $\begin{array}{c}\text { Men et al., } 2020 \\
\text { [119] }\end{array}$ & $\mathrm{U}$ & 144 (106 BC; 38 HC) & Tengzhou (China) & $106 \mathrm{EBC}(\mathrm{IC})$ & not reported & not reported & 50.6 & 600 \\
\hline $\begin{array}{c}\text { Silva et al., } 2019 \\
\text { [120] }\end{array}$ & $\mathrm{U}$ & $78(40 \mathrm{BC} ; 38 \mathrm{HC})$ & Funchal (Portugal) & not reported & not reported & not reported & 59 & 400 \\
\hline $\begin{array}{l}\text { Slupsky et al., } \\
2010[121]\end{array}$ & $\mathrm{U}$ & $\begin{array}{c}170 \text { (48 BC; } 50 \text { OC; } 72 \\
\mathrm{HC})\end{array}$ & Edmonton (Canada) & 37 IDC; 7 DCIS; 4 ILC & not reported & not reported & 56 & 600 \\
\hline
\end{tabular}

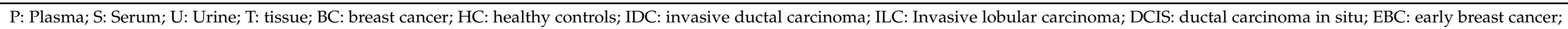

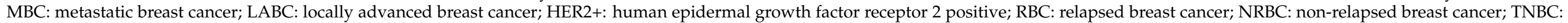

Triple-negative breast cancer. 


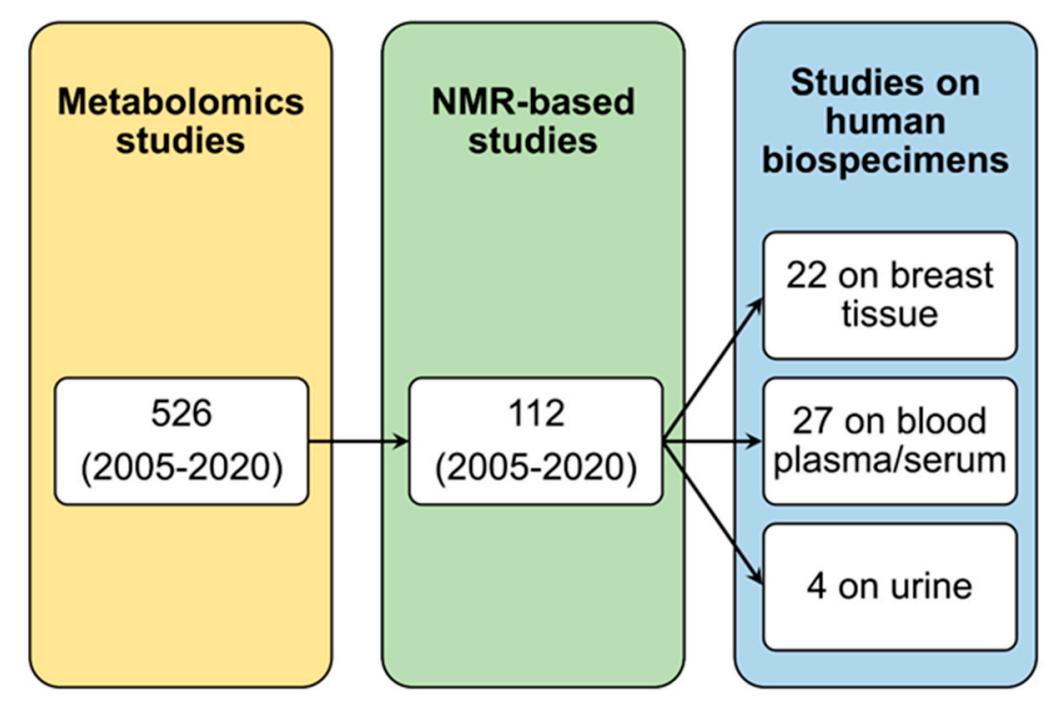

Figure 2. Selection of the scientific articles included in this NMR-based metabolomics review. The figure shows the workflow of the papers' selection.

\section{NMR Metabolomics of Breast Tissue}

High resolution magic angle spinning (HR-MAS) NMR spectroscopy allows the quantification of approximately 40 metabolites with a safe, non-destructive method that requires minimal sample preparation. Since HR-MAS analyzes intact tissue, it offers the potential to further characterize the same specimen via histopathology or utilizing transcriptomics and/or proteomics [71,90]. Several studies (Table 2) have shown that HR-MAS is able to discriminate between malignant and normal breast tissue [72,73], and between in-situ and infiltrating carcinoma [74]. Two studies have shown that the metabolic profile does not differ significantly based on intra-tumoral location and biospecimen type [75,76].

\subsection{Correlation with Clinicopathological Factors}

Metabolomics has been shown to be capable of predicting the status of $\mathrm{BC}$ prognostic factors such as estrogen receptor (ER), progesterone receptor (PR), and axillary lymph nodes (Table 3) [77]. In the study of Choi et al. [78], higher choline levels were found to correlate with ER-negative and PR-negative tumors. In addition, triple negative status (i.e., the absence of ER, PR, and HER2 receptors) was associated with higher choline-tocreatine and total choline-to-creatine ratios. In a study of Cao et al. [79], the metabolomic characterization of triple negative tumors confirmed higher choline levels, but also showed an association with lower creatine and glutamine levels, together with higher levels of glutamate, glycine, and lactate (Table 3). Tayyari et al. [80] performed a metabolic analysis to identify the potential differences between triple negative and hormone receptor-positive tumors, within both African-American and Caucasian patients. African-American patients with triple negative tumors showed higher concentrations of choline, glutamine, and glutathione compared to patients with hormone receptor-positive tumors. Conversely, Caucasian patients with triple negative tumors showed lower levels of glutamine in comparison with African-American patients with triple negative tumors.

In the context of HER2-positive tumors, Choi et al. [78] showed a significant correlation with higher levels of taurine, scyllo-inositol, and myo-inositol. Moreover, Cao et al. [79] described an association with higher concentrations of creatine, succinate, glycine and glutamine, and lower concentrations of alanine. 
Table 2. List of altered metabolite levels identified in breast tissue of breast cancer patients to study their metabolomic profiles.

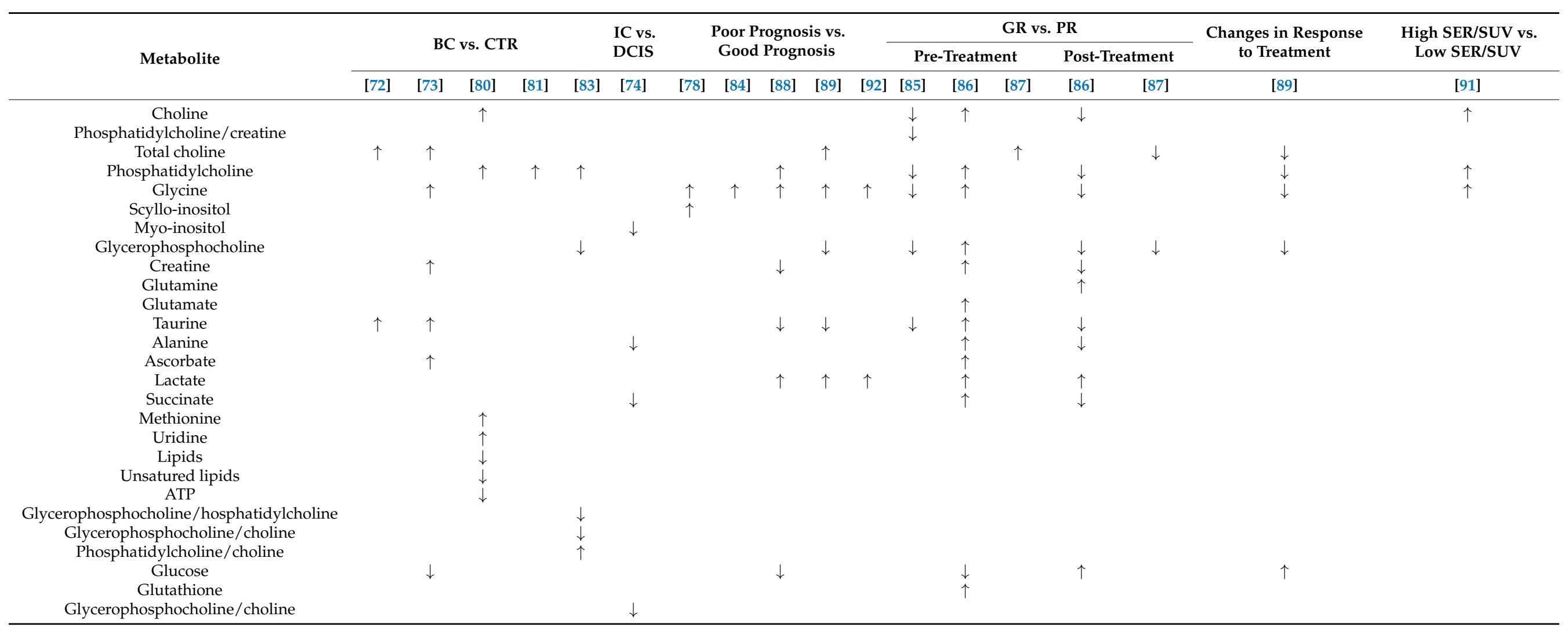

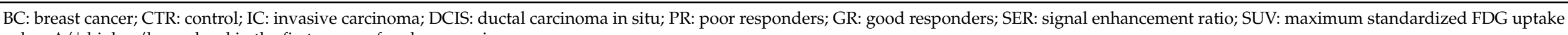
value. $\uparrow / \downarrow$ higher/lower level in the first group of each comparison. 
Table 3. List of altered metabolite levels identified in breast tissue of breast cancer patients to study clinicopathological factors.

\begin{tabular}{|c|c|c|c|c|c|c|c|c|c|c|c|c|c|c|c|c|c|c|c|}
\hline \multirow{2}{*}{ Metabolite } & \multicolumn{4}{|c|}{ ER+ vs. ER- } & \multicolumn{2}{|c|}{$\begin{array}{c}\text { PR+ vs. } \\
\text { PR- }\end{array}$} & \multicolumn{2}{|c|}{$\begin{array}{c}\text { HER2+ vs. } \\
\text { HER2- }\end{array}$} & \multicolumn{3}{|c|}{ High G vs. Low G } & \multicolumn{3}{|c|}{ TN vs. NonTN } & \multicolumn{2}{|c|}{ N+ vs. No } & \multirow{2}{*}{$\begin{array}{c}\mathrm{T}>2 \mathrm{~cm} \text { vs. } \\
\mathrm{T}<2 \mathrm{~cm} \\
{[83]}\end{array}$} & \multicolumn{2}{|c|}{$\begin{array}{l}\text { High Ki67 vs } \\
\text { Low Ki67 }\end{array}$} \\
\hline & [77] & [78] & [79] & [82] & [77] & [78] & [78] & [79] & [78] & [53] & [83] & {$[78]$} & [79] & {$[80]$} & [82] & [83] & & [78] & [84] \\
\hline Choline & $\downarrow$ & $\downarrow$ & $\downarrow$ & & $\downarrow$ & $\downarrow$ & & & & & & $\uparrow$ & $\uparrow$ & & & $\downarrow$ & $\uparrow$ & & \\
\hline Choline/creatine & & & & & & & & & & & & $\uparrow$ & & & & & & & \\
\hline Total choline/creatine & & & & & & & & & & & & $\uparrow$ & & & & & & & \\
\hline Phosphatidylcholine/creatine & & & & & & & & & $\uparrow$ & & & & & & & & & $\uparrow$ & \\
\hline Total choline & & & & & & & & & & & & & & & & & & $\uparrow$ & \\
\hline Phosphatidylcholine & $\uparrow$ & & & $\downarrow$ & $\downarrow$ & & & $\downarrow$ & & & & & $\uparrow$ & & $\uparrow$ & $\uparrow$ & & $\uparrow$ & \\
\hline Glycine & $\downarrow$ & & $\downarrow$ & $\downarrow$ & $\downarrow$ & & & $\uparrow$ & & & & & $\uparrow$ & & $\uparrow$ & $\uparrow$ & $\uparrow$ & & \\
\hline Scyllo-inositol & & & & $\downarrow$ & & & $\uparrow$ & & & & & & & & & & & & \\
\hline Myo-inositol & & & & & & & $\uparrow$ & & & & & & & & & $\uparrow$ & & & \\
\hline Glycerophosphocholine & $\downarrow$ & & & $\uparrow$ & $\downarrow$ & & & & & & $\uparrow$ & & $\uparrow$ & & & $\downarrow$ & & & \\
\hline Creatine & $\begin{array}{l}\gamma \\
\uparrow\end{array}$ & & & & $\downarrow$ & $\downarrow$ & & $\uparrow$ & & & & & $\downarrow$ & & & $\downarrow$ & & & \\
\hline Glutamine & & & $\uparrow$ & & & & & $\uparrow$ & & & & & $\downarrow$ & & & & & & \\
\hline Glutamate & & & $\downarrow$ & & & & & & & & & & $\uparrow$ & & & & & & \\
\hline Taurine & $\uparrow$ & & $v$ & $\uparrow$ & & $\downarrow$ & $\uparrow$ & & & & & & & & $\downarrow$ & $\downarrow$ & & & \\
\hline Alanine & $\downarrow$ & & & & $\downarrow$ & & & $\downarrow$ & & & & & & & & & & & \\
\hline Ascorbate & $\uparrow$ & & & & $\downarrow$ & & & & & & & & & & & & & & \\
\hline Succinate & & & & & & & & $\uparrow$ & & & & & & & & & & & \\
\hline ATP & & & & & & & & & & & & & & $\downarrow$ & & & & & \\
\hline Lactate/Choline & & & & & & & & & & $\uparrow$ & & & & & & & & & \\
\hline Betaine & & & & & & & & & & & & & & & & $\downarrow$ & & & \\
\hline Glucose & & & & & & & & & & & & & & & & $\uparrow$ & & & $\downarrow$ \\
\hline
\end{tabular}


Choline-containing compounds have been found to be correlated with tumor grade and the proliferative marker Ki67. Choi et al. [78] showed that phosphocholine-to-creatine ratio was significantly greater in high grade and highly proliferative tumors. In addition, Ki67 was associated with increased phosphatidylcholine (PC) and total choline levels. In a different study published in 1998, a higher lactate-to-choline ratio was significantly correlated with high grade tumors [81]. Axillary lymph node involvement was associated with increased glycine and phosphocholine, and reduced betaine and taurine in a study by Bathen et al. [82].

Sitter et al. [83] showed that higher choline and glycine concentrations are characteristic of tumor larger than $2 \mathrm{~cm}$ as compared with smaller tumors. A later analysis of the same group [84] correlated the metabolic profile of 29 intact BC samples with clinical prognosis. Patients with an estimated good prognosis, defined by the absence of disease in axillary lymph nodes, primary tumors smaller than $2 \mathrm{~cm}$, and ER- and PR-positive disease, were found to have a trend toward a lower concentration of glycine compared to those patients with poor prognosis. Moreover, the metabolomic analysis of tissue samples with a high proliferation index correlated with low concentrations of glucose.

\subsection{Correlation with Response to Neoadjuvant Therapy}

Metabolic profiling of breast tumor tissue using HR-MAS has been correlated with pathological response to neoadjuvant therapy in several studies (Table 2). In the study by Choi et al. [85], patients who achieved a pathological complete response (pCR) following neoadjuvant chemotherapy and subsequent surgery were compared with patients without a pCR result. No significant differences in the metabolite concentration of pretreatment samples were found between responders and non-responders. Moreover, the metabolomic profile was not able to predict pCR prior to neoadjuvant treatment in a study of Euceda et al. [86]. However, pre-treatment biopsies of responders showed lower levels of glucose and higher levels of lactate compared with non-responders. Responders also showed an increase in glucose, lactate, and glutamine levels after treatment, and a decrease in phosphocholine, choline, and succinate. Cancer cells preferentially switch from anaerobic to aerobic glycolysis as result of the Warburg effect [122]. This phenomenon is associated with rapid glucose consumption and increased lactate production. As such, the lower levels of glucose and higher lactate found in pre-treatment samples of responders could reflect a more malignant metabolic profile that paradoxically also makes cells more sensitive to chemotherapy. The increase of glucose observed after treatment may be an expression of lower glucose consumption.

Cao et al. [87] showed that the pre-treatment levels of total choline (tCho) were higher in patients with tumors responsive to neoadjuvant chemotherapy than those with nonresponsive tumors. Moreover, there was a reduction of tCho levels from pre-treatment to post-treatment samples in patients with partial response while this was not observed in patients with stable disease. However, these differences were not statistically significant. Conversely, glycerophosphorylcholine (GPC) was significantly decreased in post-treatment samples of patients in the responder group. The tCho signal is involved in cellular membrane turnover, therefore a decrease in tCho levels after treatment could suggest lower cellular proliferation.

\subsection{Correlation with Survival}

In the study by Giskeodegard et al. [88], the metabolic profile of BC tissue was correlated with 5-year survival rates. Higher levels of lactate and glycine were found to be associated with worse prognosis in patients with ER-positive BC undergoing upfront surgery without any prior treatment. This was not observed in the ER-negative subgroup, likely due to the small number of patients $(n=24)$, whilst also reflecting the metabolic differences between ER-positive and ER-negative tumors.

Similar results were found by Cao et al. [89]. In this study, increased levels of lactate on post-treatment tumor samples were associated with worse prognosis (survival < 5 years), 
while reduced levels of glycine and choline containing compounds correlated with better prognosis. Patients disease-free after five years of follow up also showed increased levels of glucose in response to treatment, in comparison with non-survivors. Conversely, pretreatment metabolic analysis of tumor samples gave no prognostic information, suggesting that the difference observed between survivors and non-survivors resulted from a metabolic response to treatment. In this study, the impact of ER status on metabolic profile variations in response to treatment was not investigated.

Debik et al. [92] analyzed tissue samples from 132 women undergoing neoadjuvant chemotherapy. The metabolic profile of tumor biopsies detected during treatment was predictive of 5-year survival. In concordance with previous studies, patients with short survival had higher lactate and glycine levels in comparison with disease-free patients at five years. Increased lactate levels after treatment may reflect the activation of aerobic glycolysis and tumor response to hypoxia that led to high tumor aggressiveness and poor prognosis. Conversely, decreased glycine and tCho levels in response to treatment may be related to altered glycolysis and reduced cell proliferation, as an expression of lower disease aggressiveness and better prognosis.

\subsection{Correlation with Transcriptomics and Proteomics}

Metabolomics has been combined with transcriptomics and proteomics to better characterize breast tumors and to identify the mechanisms underlying $\mathrm{BC}$ heterogeneity.

Metabolite, gene expression, and protein data from $228 \mathrm{BC}$ samples were analyzed by Haukaas et al. [90]. At the time of sample collection, patients had not received any treatment. HR-MAS identified three distinct metabolic clusters (MC1, MC2, and MC3). MC1 was characterized by the highest levels of GPC and phosphocholine (pCho); glucose was the most concentrated metabolite in MC2; glycine, alanine and lactate were predominant in MC3. These three clusters showed different expression of genes involved in glycolysis, gluconeogenesis, and glycerophospholipid metabolism, and genes related to extracellular matrix. They also expressed different cancer-related proteins. However, there were no significant differences in the distribution of PAM50-characterized molecular subtypes between the clusters. In a previous study merging transcriptomics and metabolomics [71], three subgroups of luminal A tumors with different metabolic profile and gene expression were identified. Thus, this supports the premise that metabolomics adds relevant information to transcriptomics and proteomics, in turn contributing to a more refined subclassification of breast tumors.

\subsection{Correlation with Quantitative Conventional Breast Imaging}

In the study by Yoon et al. [91], 53 BC specimens derived from pre-treatment core needle biopsies (CNB) were analyzed with HR-MAS. The metabolomic profile of each lesion was then correlated with conventional quantitative breast imaging parameters. It was shown that patients with high signal enhancement ratio (SER) at MRI with dynamic contrast enhanced (DCE), and with high FDG uptake value (SUV) at PET-CT scan, had higher levels of phosphatidylcholine (PC), choline and glycine. Choline was significantly correlated with SER, while PC correlated with SUV. Both these correlations were justified by the role of choline and PC in cell membrane synthesis, required for tumor cell replication and angiogenesis. High SER and SUV levels have been related to poor prognostic markers; therefore, choline and PC could be promising metabolites to be used to predict poor prognosis.

\section{NMR Metabolomics of Blood Plasma/Serum}

Circulating blood metabolites and lipoproteins may not only reflect the tumor metabolism, but more likely may provide a systemic picture of the fine balance between the tumor and the host metabolism considering the global physiological and immunological conditions of each patient with BC. For all these reasons, several aspects of the NMR-based metabolomic 
signature of $\mathrm{BC}$ in plasma/serum have been explored as providing novel insight into the molecular aspects of this disease.

\subsection{Characterization of the Metabolomics Profile of BC Patients}

Blood NMR-based metabolomics have been shown to have potential of distinguishing patients with BC with respect to healthy controls (HC) with high discrimination accuracies $[94,95,98,111,115]$. The levels of several circulating amino acids, and glyco- and lipo-proteins, have been shown to be statistically significantly altered in patients with BC (Table 4), implying a disruption of energetic homeostasis and amino acid metabolism to support cancer growth and evolution [94,95]. Recently, Jobard et al. [100] reported perturbations in circulating plasma metabolites prior to a breast cancer diagnosis in a population of 791 breast cancer cases and 791 matched controls. These alterations involved particularly histidine, N-acetyl glycoproteins (NAC), glycerol, and ethanol, but are statistically significant only in the premenopausal subgroup.

The metabolome of specific BC molecular subtypes has been also investigated. Study of the metabolomic profile of patients with triple-negative $\mathrm{BC}$ has further refined the molecular characterization of this BC subtype that accounts for $10-22 \%$ of all diagnosed $B C$ and has the worst survival rate [115]. A recent study on plasma unravels how ER status impacts on the metabolomic profiles of patients with HER2-positive BC, with metabolomic data also studied in association with levels of circulatory cytokines [99]. Blood metabolomics has also shown how high expression of the receptor for the inositol 1, 4, 5 Trisphosphate, of which deregulation promotes tumor growth and aggressiveness, influences the host system metabolome by increasing lipoprotein content and the levels of lactate, lysine, and alanine and by decreasing the levels of pyruvate and glucose [111].

Important efforts have been made in order to describe the differences on plasma/serum metabolome across EBC and metastatic breast cancer (MBC) $[97,105,108,110,113]$. These two groups of patients can be discriminated by NMR metabolomics with high accuracy, and as reported in Table 4, several metabolites showed statistically different levels in patients with $\mathrm{EBC}$ and $\mathrm{MBC}$, implying a progressive disruption and rewiring of several metabolic pathways following the evolution of the disease.

\subsection{Blood Metabolomics: Prognosis and Risk of Relapse}

Of interest to clinicians is the potential of metabolomics from a prognostic point of view. Metabolomics could provide the ability to discern between patients with EBC at high risk of recurrence, and those who may be cured by locoregional therapy alone. In the current era of precision medicine, this would represent an invaluable tool for clinicians, who may in turn offer more aggressive adjuvant therapies to the former group and sparing the latter from treatments whose benefit-risk ratio is poor [123,124]. In 2010, the first evidence supporting the usefulness of metabolomics as a potential biomarker of recurrence was published by Asiago and coauthors [40]. In this retrospective analysis, a PLS-DA model built using 11 metabolites provided a sensitivity of $86 \%$ and a specificity of $84 \%$ in discriminating patients with previous EBC free from disease at six years and patients with disease relapse. Of note, $55 \%$ of patients were correctly predicted to develop recurrence about 13 months before the clinical diagnosis of the same. 
Table 4. List of altered metabolite levels identified in plasma/serum samples of BC patients to study several aspects of this pathology.

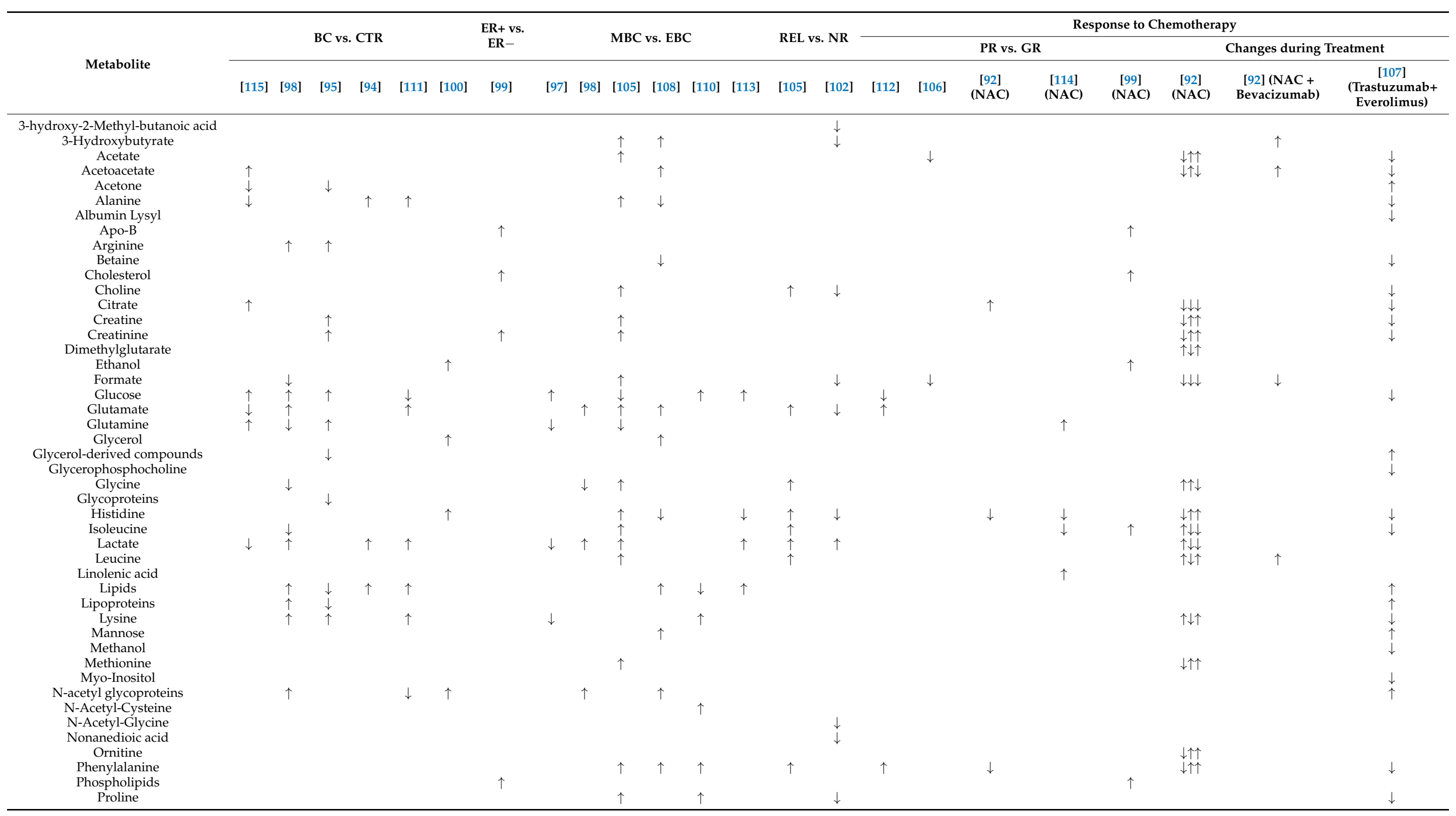


Table 4. Cont.

\begin{tabular}{|c|c|c|c|c|c|c|c|c|c|c|c|c|c|c|c|c|c|c|c|c|c|}
\hline \multirow[b]{3}{*}{ Metabolite } & \multirow{2}{*}{\multicolumn{5}{|c|}{ BC vs. CTR }} & \multirow{3}{*}{$\begin{array}{c}\begin{array}{c}\text { ER+ vs. } \\
\text { ER-- }\end{array} \\
{[99]}\end{array}$} & \multirow{2}{*}{\multicolumn{5}{|c|}{ MBC vs. ЕBC }} & \multirow{2}{*}{\multicolumn{2}{|c|}{ REL vs. NR }} & \multicolumn{8}{|c|}{ Response to Chemotherapy } \\
\hline & & & & & & & & & & & & & & \multicolumn{5}{|c|}{ PR vs. GR } & \multicolumn{3}{|c|}{ Changes during Treatment } \\
\hline & [115] & {$[98]$} & [95] & [94] & [111] [100] & & {$[97] \quad[98]$} & [105] & [108] & [110] & [113] & [105] & [102] & [112] & [106] & $\begin{array}{c}{[92]} \\
(\mathrm{NAC})\end{array}$ & $\begin{array}{c}{[114]} \\
\text { (NAC) }\end{array}$ & $\begin{array}{c}{[99]} \\
\text { (NAC) }\end{array}$ & $\begin{array}{c}{[92]} \\
\text { (NAC) }\end{array}$ & $\begin{array}{c}\text { [92] (NAC + } \\
\text { Bevacizumab) }\end{array}$ & $\begin{array}{c}{[107]} \\
\text { (Trastuzumab- } \\
\text { Everolimus) }\end{array}$ \\
\hline $\begin{array}{l}\text { Pyruvate } \\
\text { Threonine }\end{array}$ & & & & & $\downarrow$ & & $\downarrow$ & & $\uparrow$ & & & & & & & & $\uparrow$ & & $\downarrow \downarrow \uparrow$ & & \\
\hline Triglycerides & & & & & & & & & & & & & & & & & $T$ & $\uparrow$ & & & \\
\hline $\begin{array}{l}\text { Tyrosine } \\
\text { Unsaturated lipids }\end{array}$ & $\downarrow$ & $\uparrow$ & $\downarrow$ & & & & & $\uparrow$ & & & $\uparrow$ & $\uparrow$ & $\uparrow$ & & & & & & & & $\downarrow$ \\
\hline Valine & & $\downarrow$ & $\uparrow$ & $\uparrow$ & & & & & & & & $\uparrow$ & & & & & & $\uparrow$ & $\downarrow \uparrow \uparrow$ & & $\downarrow$ \\
\hline
\end{tabular}

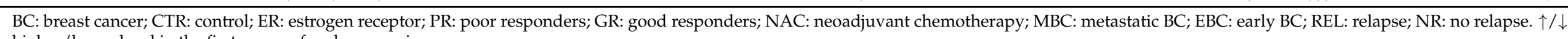
higher/lower level in the first group of each comparison. 
Over the past years our group has pursued this research line establishing a reproducible method of quantifying individual serum metabolomic fingerprints and demonstrating, in monocentric and multicentric cohorts of patients, its ability to accurately discriminate between MBC and EBC [105,109,110,113]. Furthermore, our data have shown that patients with EBC classified as "metastatic" on the basis of their metabolomic fingerprints presented high risk of disease recurrence. Thus, we hypothesized that EBC patients with occult micro-metastatic disease may already have features of the metastatic signature in their metabolomic fingerprint, and that this signature may be predictive for relapse. Following this approach, in a monocentric cohort of ER negative EBC patients we were able to predict cancer relapse with $82 \%$ accuracy [113]. These results have been reproduced obtaining $71 \%$ predictive accuracy by analyzing serum samples collected in several centers in South-East Asia, as a part of an unrelated Phase III adjuvant trial, from an heterogenous group of patients with mainly ER positive EBC [105]. Moreover, we have demonstrated that the serum NMR-based metabolomic fingerprinting approach can be effectively utilized to further refining the genomic risk of relapse predicted using the OncotypeDX 21-gene expression assay risk recurrence score [109].

\subsection{Pharmacometabolomics in Breast Cancer Setting}

The application of metabolomics for the study of drug effects and response-the so-called pharmacometabolomics - can contribute to personalized drug therapy [125], with relevant examples of its applications in the setting of $\mathrm{BC}$ already having been published. The primary aim of metabolomics in this context is to predict which patients will benefit most from a specific treatment. First in 2012, our group demonstrated that metabolomics may play a role in identifying patients with MBC with HER2-positive disease with a greater sensitivity to paclitaxel plus the anti-HER2 agent lapatinib [112]. Jiang and colleagues utilized NMR-based pharmacometabolomics to predict response to gemcitabine/carboplatin chemotherapy in a population of 29 patients with MBC. Baseline serum levels of formate and acetate were identified as potential predictive biomarkers of chemotherapy response [106]. In postmenopausal BC women treated with chemotherapy, the combination of lactate, alanine, and glucose has been associated with cancer progression [104]; moreover, high basal lactate levels were correlated with weight gain in postmenopausal women receiving chemotherapy [101].

More recently, some metabolomics studies have focused their attention on neoadjuvant chemotherapy (NAC). In breast cancer, NAC has become the approach of choice for patients with large primary tumors and for locally advanced disease [126]. The neoadjuvant approach offers the advantage of downstaging disease and reducing the size of tumors prior to surgery, thus making patients with inoperable tumors candidates for surgical resection or enabling breast-conserving surgery rather than mastectomy [92,126]. However, less than $30 \%$ of patients overall show complete $\mathrm{pCR}$ to NAC [114], with lower rates of response found in ER-positive, HER2-negative disease. Published metabolomic studies have been targeted at predicting response to NAC to enable the development of personalized treatment protocols, and at characterizing the effects of NAC on the metabolome $[92,99,107,114]$. Plasma/serum metabolomics has been shown to be effective in predicting $\mathrm{PCR}$ in different NAC regimes [99,114]. Moreover, it has been demonstrated that NAC induces relevant changes in patient metabolism during treatment, and that these alterations also persist some weeks after the completion of systemic therapy [92,107]. In particular, in the study conducted by Jobard et al. [107], the effects of trastuzumab and everolimus in combination were associated with alterations that involve several metabolic pathways reflecting a systemic effect, particularly on the liver and visceral fat.

\subsection{NMR Lipidomics in Breast Cancer}

Lipidomics represents a relatively new and promising complement to the more classical NMR metabolomics. In this particular setting, MS has been for a long time the preferred technology, however recent advancements on NMR analysis of blood plasma and serum 
have permitted its wider use. The Bruker IVDr Lipoprotein Subclass Analysis platform ${ }^{\mathrm{TM}}$ (Bruker Biospin) has enabled a fast and reliable quantification of the main lipoprotein parameters and their subfractions. This tool utilizes a chemometric approach based on a PLS regression model to perform lipoprotein subclass analysis on ${ }^{1} \mathrm{H}$ NMR NOESY spectra $[64,127]$.

The lipoproteins analysis via NMR was capable of providing further insights into the host metabolic alterations induced by different clinicopathological factors: HDL subfraction contents were strongly associated with PgR expression, whereas Ki67 expression was inversely associated with HDL phospholipids. Conversely no correlation was observed between lipoproteins and ER expression. This metabolic information could be relevant to characterize breast tumor aggressiveness and prognosis [116]. Moreover, it has been observed that women characterized by lower plasma levels of lipoproteins, lipids, glycoproteins, acetone, glycerol-derived compounds, and unsaturated lipids present a higher risk of developing BC over time [95].

Relevant alterations of the lipoproteins' profiles of $\mathrm{BC}$ patients were also observed in association with chemotherapy treatments. In particular, alterations of HDL, LDL, VLDL cholesterols and triglycerides were observed during and after treatments. These observations were hypothesized to be related to inflammation processes and lipids homeostasis $[107,117]$.

\section{NMR Metabolomics of Urine}

Although urine samples can be easily and non-invasively collected in large volumes, and require minimal pre-analytical and analytical preparation, the NMR-based urinary metabolome of patients with BC is relatively unexplored to date. Indeed, database research located only four published research articles.

In 2010, Slupsky and coauthors [121] described for the first time the urinary metabolic phenotype of a population of 48 patients with BC via NMR. Patients with BC in comparison to controls showed significantly lower levels of several metabolites (Table 5). However, the $\mathrm{BC}$ group was very heterogenous in terms of histologic types (including both invasive ductal and lobular carcinoma, as well as ductal carcinoma in situ), lymph node status (10 patients had at least one positive lymph node), and age (ranging from 30 to 86). These factors, if not properly considered, can present significant confounding factors. To date, other three research articles (Table 1) have been published [118-120] comparing the metabolic profiles of patients with $\mathrm{BC}$ to those of healthy controls. These studies confirmed the reduction of excretion levels of several metabolites, with the exception of citrate which showed a controversial trend (Table 5). The study by Men and coauthors [119] also examined the urinary levels of heavy metals, with As, Cd, and Cr significantly increased in the urine of patients with $\mathrm{BC}$ compared to controls. This finding suggests that urine concentrations of heavy metals and BC development could be associated.

Although these published results are thought provoking and point to relevant metabolite dysregulations in patients with BC, no large-scale study-mono- or multicenter-has been performed to date. Moreover, clinically relevant markers and outcomes (i.e., cancer stage, cancer recurrence, response to therapy) have never been explored via urine metabolomics. 
Table 5. List of altered metabolite levels identified in urine samples of BC patients with respect to healthy controls.

\begin{tabular}{|c|c|c|c|c|}
\hline \multirow{2}{*}{ Metabolite } & \multicolumn{4}{|c|}{ Studies on Urine Samples } \\
\hline & [119] & [120] & [121] & [118] \\
\hline 2-oxoisocaproate & $\downarrow$ & & & \\
\hline 3-methylglutarate & $\downarrow$ & & & \\
\hline 4-cresol sulphate & & $\downarrow$ & & \\
\hline 4-hydroxyphenylacetate & & & $\downarrow$ & \\
\hline acetate & & $\downarrow$ & $\downarrow$ & \\
\hline acetone & & $\downarrow$ & & \\
\hline alanine & $\downarrow$ & $\downarrow$ & $\downarrow$ & \\
\hline asparagine & & & $\downarrow$ & \\
\hline betaine & & $\downarrow$ & & \\
\hline carnitine & & $\downarrow$ & & \\
\hline choline & & $\downarrow$ & & \\
\hline cis-aconitate & & $\downarrow$ & & \\
\hline citrate & & $\downarrow$ & & $\uparrow$ \\
\hline creatine & & $\downarrow$ & $\downarrow$ & \\
\hline creatinine & $\downarrow$ & $\downarrow$ & $\downarrow$ & \\
\hline dimethylamine & $\downarrow$ & $\downarrow$ & $\downarrow$ & \\
\hline ethanolamine & & & $\downarrow$ & \\
\hline formate & & $\uparrow$ & $\downarrow$ & \\
\hline glucose & & & $\downarrow$ & \\
\hline glutamate (n-acetylaminoacides) & $\downarrow$ & & & \\
\hline glutamine & $\downarrow$ & $\downarrow$ & & \\
\hline glycine & $\downarrow$ & $\downarrow$ & & \\
\hline guanidoacetate & & $\downarrow$ & & $\downarrow$ \\
\hline hippurate & $\downarrow$ & & $\downarrow$ & \\
\hline histamine & $\downarrow$ & & & \\
\hline hypoxanthine & & $\downarrow$ & & \\
\hline isoleucine & $\downarrow$ & & $\downarrow$ & \\
\hline lactate & & $\downarrow$ & $\downarrow$ & \\
\hline leucine & $\downarrow$ & & $\downarrow$ & \\
\hline levoglucosan & & & $\downarrow$ & \\
\hline lysine & $\downarrow$ & & & \\
\hline malonate & $\downarrow$ & & & \\
\hline mannitol & & $\downarrow$ & & \\
\hline methylhistidine & $\downarrow$ & & & \\
\hline phenylacetylglycine & & & & $\downarrow$ \\
\hline pyroglutamate & & & $\downarrow$ & \\
\hline pyruvate & & $\downarrow$ & & \\
\hline serine & & $\downarrow$ & & \\
\hline succinate & & $\downarrow$ & $\downarrow$ & \\
\hline sucrose & & & $\downarrow$ & \\
\hline taurine & $\downarrow$ & $\downarrow$ & & \\
\hline threonine & & $\downarrow$ & $\downarrow$ & \\
\hline trans-aconitate & & & $\downarrow$ & \\
\hline trigonelline & & $\downarrow$ & & \\
\hline trimethylamine n-oxide & $\downarrow$ & $\downarrow$ & & \\
\hline uracil & & & $\downarrow$ & \\
\hline urea & & & $\downarrow$ & \\
\hline valine & $\downarrow$ & $\downarrow$ & $\downarrow$ & \\
\hline$\alpha$-hydroxybutyrate & & $\uparrow$ & & \\
\hline$\alpha$-hydroxyisobutyrate & & $\downarrow$ & & \\
\hline$\alpha$-oxoglutarate & & $\downarrow$ & & \\
\hline$\beta$-hydroxyisobutyrate & $\downarrow$ & & & \\
\hline$\beta$-hydroxyisovalerate & & $\downarrow$ & & \\
\hline
\end{tabular}




\section{Translation of NMR-Based Metabolomics in Clinics}

This review aimed at highlighting the relevant results obtained using metabolomics by NMR in the $\mathrm{BC}$ setting and the possible role of this approach in the clinical practice.

$\mathrm{BC}$ is the most common type of cancer and the second most common cause of death in women worldwide [128]. Early detection and prompt treatment has been associated with a significantly improved prognosis observed over time in patients with BC.

The serum tumor markers, CEA and CA 15.3, are routinely used in therapy monitoring and follow up of patients with BC; conversely, their sensitivity and specificity for early diagnosis are poor [129]. Mammography is considered the gold standard in BC screening, however it has a sensitivity of $86.9 \%$ with relevant variability depending on tissue density and age [130].

Malignant tumors are characterized by increased gluconeogenesis, glycolysis, and fat mobilization, and decreased protein synthesis. The results described in the previous paragraphs show that these metabolic changes peculiar to malignant neoplastic change can be detected by metabolomics. Metabolomics is able to discriminate between cancer and normal breast tissue from the same patient with accuracy, sensitivity, and specificity around $90 \%$ [73]. Moreover, the metabolite analysis of blood and urine samples from BC patients differs significantly from healthy controls $[94,95,98,111,115,131,132]$. This evidence offers potential for the use of metabolomics, a minimally invasive technique, for early diagnosis of $\mathrm{BC}$ in the general population [133].

$\mathrm{BC}$ is a heterogeneous disease with high variability in prognosis and response to treatment driven by genetic, epigenetic, and phenotypic differences. The identification of the mechanisms underpinning this heterogeneity support the development of new drugs targeted to specific subgroup of patients, with the final aim to improve patient outcome. Transcriptomics and proteomics have attempted to classify breast tumors according to gene expression (intrinsic molecular subtypes-[134]) and protein expression (RPPA subtypes-[135]). As shown in the previous sections of this review, metabolomics can provide additional information to these -omics, leading to a deeper tumor characterization. ER and HER2 status are well estimated by metabolite analysis [79]. In addition, metabolomics can identify metabolic clusters within breast tumors, not reflecting the intrinsic molecular subtypes, but presenting significant differences in gene expression and protein expression profiles, and unique susceptibility to metabolically targeted drugs [90].

Neoadjuvant chemotherapy is commonly used to treat BC, not only for downsizing tumors, but also for the potential to monitor individual drug response. Moreover, in selected molecular subtypes, the achievement of a $\mathrm{pCR}$ after neoadjuvant treatment correlates with excellent long-term outcomes and a lower risk of disease recurrence [136]. Currently HER2 positivity, triple negative subtype, high Ki67, and the presence of tumor infiltrating lymphocytes (TILs) are the biomarkers most frequently used in recommending neoadjuvant chemotherapy. Predicting response to chemotherapy can spare patients with unresponsive disease from unnecessary side effects. Metabolomics was shown to play a role in predicting response to NAC.

We have summarized in this review that metabolomic profiling of serum samples collected before neoadjuvant chemotherapy was able to predict response in two small cohorts of patients. The first cohort was unselected for molecular subtype [114], while the second included only HER2-positive breast tumors [137]. The potential role of metabolomics in predicting response to treatment was also evaluated on breast tumor tissue. This analysis demonstrated that tumor metabolism changed significantly in response to neoadjuvant treatment. Metabolomic analysis on post-treatment tissue samples was able to discriminate between patients who experienced disease response to treatment and those who had non-responsive cancer. However, metabolomic analysis of pre-treatment tumor biopsies was not predictive probability of response to chemotherapy [85-87].

Developing prognostic biomarkers is one of the focuses of metabolomics in BC. Clinicopathological features are used to predict the risk of recurrence or development of metastatic disease. More recently, gene-expression assays such as Oncotype DX and Mammaprint 
have been introduced in clinical practice to refine risk estimation and prediction from adjuvant chemotherapy. However, these assays are time consuming, expensive, and can overestimate the risk of recurrence [138]. In addition, they are estimated on the primary tumor tissue and cannot identify the presence or absence of occult micro-metastases. Metabolomics can contribute to overcoming these limitations. As already detailed in the above paragraphs, our group developed a metabolomic score that classified patients as high or low risk of recurrent disease on the basis of the degree of metabolomic similarities with MBC fingerprints $[105,113]$. A high metabolomic score correlates with increased risk of recurrence and worse disease-free survival. Moreover, this metabolomic risk score can be used to sub-stratify the three Oncotype DX risk categories [109].

However, how far are we now from adopting NMR-based metabolomics as a populationwide screening method? The conceptual distance from the present situation to this ambitious goal is still wide, but it can be bridged by working in two directions: first it is necessary to standardize both the pre-analytical and the analytical procedures. Indeed, the biochemical composition of biospecimens is affected by how samples are collected, stored, prepared, and analyzed, and consequently differences in these steps can be particularly detrimental in multi-center studies [139]. Specifications for pre-examination processes for metabolomics in urine, venous blood serum and plasma have been already published by CEN (CEN/TS 16945:2016) [140]; however, these recommendations are still not universally employed. Secondly, to increase the robustness and the reliability of the results already provided, well-planned, large-scale, multicenter, population-based studies in which all heterogeneous BC patient groups are well represented are needed. NMR-based metabolomics is a fast, high-throughput, robust, and reproducible technique, thus moving from the analysis of hundreds to thousands of samples is realistically an approachable target $[19,141]$.

\section{Conclusions}

The NMR-based metabolomics studies presented in this review have demonstrated that a metabolic signature of BC exists and can be detected in breast tissue, blood serum/ plasma, and urine. This approach has the potential to improve early diagnosis of $\mathrm{BC}$, to allow early prediction of recurrence and estimating prognosis, and to further stratify the heterogenous spectra of $\mathrm{BC}$ patients and the individual response to (neo)adjuvant treatments. Metabolomics by NMR can play a pivotal role in precision oncology and it is mature enough to support, and eventually sub-stratify, the identification of risk groups obtained by clinical and genomic tools already in use.

Author Contributions: Conceptualization, A.V., E.R., L.T.; literature review, A.V. and E.R.; writingoriginal draft preparation, A.V., E.R. and L.T.; writing-review and editing, A.V., E.R., A.M., I.M., E.M., L.M., C.L., L.B. and L.T.; supervision, L.M., C.L., L.B., and L.T. All authors have read and agreed to the published version of the manuscript.

Funding: This research received no external funding.

Conflicts of Interest: The authors declare no conflict of interest.

\section{References}

1. Lerner, H.J.; Band, P.R.; Israel, L.; Leung, B.S. Phase II Study of Tamoxifen: Report of 74 Patients with Stage IV Breast Cancer. Cancer Treat. Rep. 1976, 60, 1431-1435.

2. Wiggans, R.G.; Woolley, P.V.; Smythe, T.; Hoth, D.; Macdonald, J.S.; Green, L.; Schein, P.S. Phase-II Trial of Tamoxifen in Advanced Breat Cancer. Cancer Chemother. Pharm. 1979, 3, 45-48. [CrossRef] [PubMed]

3. Early Breast Cancer Trialists' Collaborative Group (EBCTCG). Effects of Chemotherapy and Hormonal Therapy for Early Breast Cancer on Recurrence and 15-Year Survival: An Overview of the Randomised Trials. Lancet 2005, 365, 1687-1717. [CrossRef]

4. Slamon, D.; Eiermann, W.; Robert, N.; Pienkowski, T.; Martin, M.; Press, M.; Mackey, J.; Glaspy, J.; Chan, A.; Pawlicki, M.; et al. Adjuvant Trastuzumab in HER2-Positive Breast Cancer. N. Engl. J. Med. 2011, 365, 1273-1283. [CrossRef]

5. Von Minckwitz, G.; Procter, M.; de Azambuja, E.; Zardavas, D.; Benyunes, M.; Viale, G.; Suter, T.; Arahmani, A.; Rouchet, N.; Clark, E.; et al. Adjuvant Pertuzumab and Trastuzumab in Early HER2-Positive Breast Cancer. N. Engl. J. Med. 2017, 377, 122-131. [CrossRef] 
6. Von Minckwitz, G.; Huang, C.-S.; Mano, M.S.; Loibl, S.; Mamounas, E.P.; Untch, M.; Wolmark, N.; Rastogi, P.; Schneeweiss, A.; Redondo, A.; et al. Trastuzumab Emtansine for Residual Invasive HER2-Positive Breast Cancer. N. Engl. J. Med. 2019, 380, 617-628. [CrossRef]

7. Gianni, L.; Pienkowski, T.; Im, Y.-H.; Roman, L.; Tseng, L.-M.; Liu, M.-C.; Lluch, A.; Staroslawska, E.; de la Haba-Rodriguez, J.; Im, S.-A.; et al. Efficacy and Safety of Neoadjuvant Pertuzumab and Trastuzumab in Women with Locally Advanced, Inflammatory, or Early HER2-Positive Breast Cancer (NeoSphere): A Randomised Multicentre, Open-Label, Phase 2 Trial. Lancet Oncol. 2012, 13, 25-32. [CrossRef]

8. Martin, M.; Holmes, F.A.; Ejlertsen, B.; Delaloge, S.; Moy, B.; Iwata, H.; von Minckwitz, G.; Chia, S.K.L.; Mansi, J.; Barrios, C.H.; et al. Neratinib after Trastuzumab-Based Adjuvant Therapy in HER2-Positive Breast Cancer (ExteNET): 5-Year Analysis of a Randomised, Double-Blind, Placebo-Controlled, Phase 3 Trial. Lancet Oncol. 2017, 18, 1688-1700. [CrossRef]

9. Swain, S.M.; Kim, S.-B.; Cortés, J.; Ro, J.; Semiglazov, V.; Campone, M.; Ciruelos, E.; Ferrero, J.-M.; Schneeweiss, A.; Knott, A.; et al. Pertuzumab, Trastuzumab, and Docetaxel for HER2-Positive Metastatic Breast Cancer (CLEOPATRA Study): Overall Survival Results from a Randomised, Double-Blind, Placebo-Controlled, Phase 3 Study. Lancet Oncol. 2013, 14, 461-471. [CrossRef]

10. Verma, S.; Miles, D.; Gianni, L.; Krop, I.E.; Welslau, M.; Baselga, J.; Pegram, M.; Oh, D.-Y.; Diéras, V.; Guardino, E.; et al. Trastuzumab Emtansine for HER2-Positive Advanced Breast Cancer. N. Engl. J. Med. 2012, 367, 1783-1791. [CrossRef]

11. Audeh, W.; Blumencranz, L.; Kling, H.; Trivedi, H.; Srkalovic, G. Prospective Validation of a Genomic Assay in Breast Cancer: The 70-Gene MammaPrint Assay and the MINDACT Trial. Acta Med. Acad. 2019, 48, 18-34. [CrossRef] [PubMed]

12. Sestak, I.; Martín, M.; Dubsky, P.; Kronenwett, R.; Rojo, F.; Cuzick, J.; Filipits, M.; Ruiz, A.; Gradishar, W.; Soliman, H.; et al. Prediction of Chemotherapy Benefit by EndoPredict in Patients with Breast Cancer Who Received Adjuvant Endocrine Therapy plus Chemotherapy or Endocrine Therapy Alone. Breast Cancer Res. Treat. 2019, 176, 377-386. [CrossRef] [PubMed]

13. Wallden, B.; Storhoff, J.; Nielsen, T.; Dowidar, N.; Schaper, C.; Ferree, S.; Liu, S.; Leung, S.; Geiss, G.; Snider, J.; et al. Development and Verification of the PAM50-Based Prosigna Breast Cancer Gene Signature Assay. BMC Med. Genom. 2015, 8, 54. [CrossRef] [PubMed]

14. Paik, S.; Tang, G.; Shak, S.; Kim, C.; Baker, J.; Kim, W.; Cronin, M.; Baehner, F.L.; Watson, D.; Bryant, J.; et al. Gene Expression and Benefit of Chemotherapy in Women with Node-Negative, Estrogen Receptor-Positive Breast Cancer. J. Clin. Oncol. 2006, 24, 3726-3734. [CrossRef]

15. Albain, K.S.; Barlow, W.E.; Shak, S.; Hortobagyi, G.N.; Livingston, R.B.; Yeh, I.-T.; Ravdin, P.; Bugarini, R.; Baehner, F.L.; Davidson, N.E.; et al. Prognostic and Predictive Value of the 21-Gene Recurrence Score Assay in Postmenopausal Women with Node-Positive, Oestrogen-Receptor-Positive Breast Cancer on Chemotherapy: A Retrospective Analysis of a Randomised Trial. Lancet Oncol. 2010, 11, 55-65. [CrossRef]

16. Sparano, J.A.; Gray, R.J.; Makower, D.F.; Pritchard, K.I.; Albain, K.S.; Hayes, D.F.; Geyer, C.E.; Dees, E.C.; Goetz, M.P.; Olson, J.A.; et al. Adjuvant Chemotherapy Guided by a 21-Gene Expression Assay in Breast Cancer. N. Engl. J. Med. 2018, 379, 111-121. [CrossRef]

17. Kalinsky, K.; Barlow, W.E.; Meric-Bernstam, F.; Gralow, J.R.; Albain, K.S.; Hayes, D.; Lin, N.; Perez, E.A.; Goldstein, L.J.; Chia, S.; et al. Abstract GS3-00: First Results from a Phase III Randomized Clinical Trial of Standard Adjuvant Endocrine Therapy (ET) +/Chemotherapy (CT) in Patients (Pts) with 1-3 Positive Nodes, Hormone Receptor-Positive (HR+) and HER2-Negative (HER2-) Breast Cancer (BC) with Recurrence Score (RS) <25: SWOG S1007 (RxPonder). Cancer Res. 2021, 81. [CrossRef]

18. Nicholson, J.K.; Lindon, J.C. Systems Biology: Metabonomics. Nature 2008, 455, 1054-1056. [CrossRef]

19. Vignoli, A.; Ghini, V.; Meoni, G.; Licari, C.; Takis, P.G.; Tenori, L.; Turano, P.; Luchinat, C. High-Throughput Metabolomics by 1D NMR. Angew. Chem. Int. Ed. Engl. 2019, 58, 968-994. [CrossRef]

20. Takis, P.G.; Ghini, V.; Tenori, L.; Turano, P.; Luchinat, C. Uniqueness of the NMR Approach to Metabolomics. Trac. Trends Anal. Chem. 2019, 120, 115300. [CrossRef]

21. Vignoli, A.; Tenori, L.; Giusti, B.; Takis, P.G.; Valente, S.; Carrabba, N.; Balzi, D.; Barchielli, A.; Marchionni, N.; Gensini, G.F.; et al. NMR-Based Metabolomics Identifies Patients at High Risk of Death within Two Years after Acute Myocardial Infarction in the AMI-Florence II Cohort. BMC Med. 2019, 17, 3. [CrossRef] [PubMed]

22. Zhang, L.; Zhu, B.; Zeng, Y.; Shen, H.; Zhang, J.; Wang, X. Clinical Lipidomics in Understanding of Lung Cancer: Opportunity and Challenge. Cancer Lett. 2020, 470, 75-83. [CrossRef] [PubMed]

23. Bertini, I.; Cacciatore, S.; Jensen, B.V.; Schou, J.V.; Johansen, J.S.; Kruhøffer, M.; Luchinat, C.; Nielsen, D.L.; Turano, P. Metabolomic NMR Fingerprinting to Identify and Predict Survival of Patients with Metastatic Colorectal Cancer. Cancer Res. 2012, 72, 356-364. [CrossRef] [PubMed]

24. Brindle, J.T.; Antti, H.; Holmes, E.; Tranter, G.; Nicholson, J.K.; Bethell, H.W.L.; Clarke, S.; Schofield, P.M.; McKilligin, E.; Mosedale, D.E.; et al. Rapid and Noninvasive Diagnosis of the Presence and Severity of Coronary Heart Disease Using 1H-NMR-Based Metabonomics. Nat. Med. 2002, 8, 1439-1444. [CrossRef]

25. Wishart, D.S. Emerging Applications of Metabolomics in Drug Discovery and Precision Medicine. Nat. Rev. Drug Discov. 2016, 15, 473-484. [CrossRef]

26. Vignoli, A.; Orlandini, B.; Tenori, L.; Biagini, M.R.; Milani, S.; Renzi, D.; Luchinat, C.; Calabrò, A.S. Metabolic Signature of Primary Biliary Cholangitis and Its Comparison with Celiac Disease. J. Proteome. Res. 2019, 18, 1228-1236. [CrossRef] [PubMed]

27. Albenberg, L.G.; Wu, G.D. Diet and the Intestinal Microbiome: Associations, Functions, and Implications for Health and Disease. Gastroenterology 2014, 146, 1564-1572. [CrossRef] [PubMed] 
28. Vignoli, A.; Tenori, L.; Giusti, B.; Valente, S.; Carrabba, N.; Baizi, D.; Barchielli, A.; Marchionni, N.; Gensini, G.F.; Marcucci, R.; et al. Differential Network Analysis Reveals Metabolic Determinants Associated with Mortality in Acute Myocardial Infarction Patients and Suggests Potential Mechanisms Underlying Different Clinical Scores Used to Predict Death. J. Proteome Res. 2020, 19, 949-961. [CrossRef]

29. Shah, S.H.; Kraus, W.E.; Newgard, C.B. Metabolomic Profiling for Identification of Novel Biomarkers and Mechanisms Related to Common Cardiovascular Diseases: Form and Function. Circulation 2012, 126, 1110-1120. [CrossRef]

30. Basoglu, A.; Baspinar, N.; Tenori, L.; Vignoli, A.; Yildiz, R. Plasma Metabolomics in Calves with Acute Bronchopneumonia. Metabolomics 2016, 12, 128. [CrossRef]

31. Rittweger, J.; Albracht, K.; Fluck, M.; Ruoss, S.; Brocca, L.; Longa, E.; Moriggi, M.; Seynnes, O.; Di Giulio, I.; Tenori, L.; et al Sarcolab Pilot Study into Skeletal Muscle's Adaptation to Longterm Spaceflight. NPJ Microgravity 2018, 4, 18. [CrossRef] [PubMed]

32. Basoglu, A.; Baspinar, N.; Tenori, L.; Vignoli, A.; Gulersoy, E. Effects of Boron Supplementation on Peripartum Dairy Cows' Health. Biol. Trace Elem. Res. 2017, 179, 218-225. [CrossRef] [PubMed]

33. Calvani, R.; Brasili, E.; Praticò, G.; Sciubba, F.; Roselli, M.; Finamore, A.; Marini, F.; Marzetti, E.; Miccheli, A. Application of NMR-Based Metabolomics to the Study of Gut Microbiota in Obesity. J. Clin. Gastroenterol. 2014, 48 (Suppl. S1), S5-S7. [CrossRef]

34. Vignoli, A.; Tenori, L.; Luchinat, C.; Saccenti, E. Age and Sex Effects on Plasma Metabolite Association Networks in Healthy Subjects. J. Proteome Res. 2018, 17, 97-107. [CrossRef] [PubMed]

35. Vignoli, A.; Rodio, D.M.; Bellizzi, A.; Sobolev, A.P.; Anzivino, E.; Mischitelli, M.; Tenori, L.; Marini, F.; Priori, R.; Scrivo, R.; et al. NMR-Based Metabolomic Approach to Study Urine Samples of Chronic Inflammatory Rheumatic Disease Patients. Anal. Bioanal. Chem. 2017, 409, 1405-1413. [CrossRef]

36. Psychogios, N.; Hau, D.D.; Peng, J.; Guo, A.C.; Mandal, R.; Bouatra, S.; Sinelnikov, I.; Krishnamurthy, R.; Eisner, R.; Gautam, B.; et al. The Human Serum Metabolome. PLoS ONE 2011, 6, e16957. [CrossRef]

37. Assfalg, M.; Bertini, I.; Colangiuli, D.; Luchinat, C.; Schäfer, H.; Schütz, B.; Spraul, M. Evidence of Different Metabolic Phenotypes in Humans. Proc. Natl. Acad. Sci. USA 2008, 105, 1420-1424. [CrossRef]

38. Wallner-Liebmann, S.; Tenori, L.; Mazzoleni, A.; Dieber-Rotheneder, M.; Konrad, M.; Hofmann, P.; Luchinat, C.; Turano, P.; Zatloukal, K. Individual Human Metabolic Phenotype Analyzed by (1)H NMR of Saliva Samples. J. Proteome Res. 2016, 15, 1787-1793. [CrossRef]

39. Romano, F.; Meoni, G.; Manavella, V.; Baima, G.; Mariani, G.M.; Cacciatore, S.; Tenori, L.; Aimetti, M. Effect of Non-Surgical Periodontal Therapy on Salivary Metabolic Fingerprint of Generalized Chronic Periodontitis Using Nuclear Magnetic Resonance Spectroscopy. Arch. Oral Biol. 2018, 97, 208-214. [CrossRef]

40. Bertini, I.; Luchinat, C.; Miniati, M.; Monti, S.; Tenori, L. Phenotyping COPD by 1H NMR Metabolomics of Exhaled Breath Condensate. Metabolomics 2013, 10, 302-311. [CrossRef]

41. Montuschi, P.; Paris, D.; Melck, D.; Lucidi, V.; Ciabattoni, G.; Raia, V.; Calabrese, C.; Bush, A.; Barnes, P.J.; Motta, A. NMR Spectroscopy Metabolomic Profiling of Exhaled Breath Condensate in Patients with Stable and Unstable Cystic Fibrosis. Thorax 2012, 67, 222-228. [CrossRef] [PubMed]

42. Montuschi, P.; Santini, G.; Mores, N.; Vignoli, A.; Macagno, F.; Shohreh, R.; Tenori, L.; Zini, G.; Fuso, L.; Mondino, C.; et al. Breathomics for Assessing the Effects of Treatment and Withdrawal with Inhaled Beclomethasone/Formoterol in Patients with COPD. Front. Pharm. 2018, 9. [CrossRef] [PubMed]

43. Vignoli, A.; Paciotti, S.; Tenori, L.; Eusebi, P.; Biscetti, L.; Chiasserini, D.; Scheltens, P.; Turano, P.; Teunissen, C.; Luchinat, C.; et al. Fingerprinting Alzheimer's Disease by $1 \mathrm{H}$ Nuclear Magnetic Resonance Spectroscopy of Cerebrospinal Fluid. J. Proteome Res. 2020, 19, 1696-1705. [CrossRef]

44. Wishart, D.S.; Lewis, M.J.; Morrissey, J.A.; Flegel, M.D.; Jeroncic, K.; Xiong, Y.; Cheng, D.; Eisner, R.; Gautam, B.; Tzur, D.; et al. The Human Cerebrospinal Fluid Metabolome. J. Chromatogr. B 2008, 871, 164-173. [CrossRef]

45. Graça, G.; Duarte, I.F.; Goodfellow, B.J.; Carreira, I.M.; Couceiro, A.B.; do Rosário Domingues, M.; Spraul, M.; Tseng, L.-H.; Gil, A.M. Metabolite Profiling of Human Amniotic Fluid by Hyphenated Nuclear Magnetic Resonance Spectroscopy. Anal. Chem. 2008, 80, 6085-6092. [CrossRef] [PubMed]

46. Gowda, G.A.N.; Shanaiah, N.; Cooper, A.; Maluccio, M.; Raftery, D. Bile Acids Conjugation in Human Bile Is Not Random: New Insights from 1H-NMR Spectroscopy at $800 \mathrm{MHz}$. Lipids 2009, 44, 527-535. [CrossRef] [PubMed]

47. Lacitignola, L.; Fanizzi, F.P.; Francioso, E.; Crovace, A. 1H NMR Investigation of Normal and Osteo-Arthritic Synovial Fluid in the Horse. Vet. Comp. Orthop. Traumatol. 2008, 21, 85-88. [CrossRef]

48. Hügle, T.; Kovacs, H.; Heijnen, I.A.F.M.; Daikeler, T.; Baisch, U.; Hicks, J.M.; Valderrabano, V. Synovial Fluid Metabolomics in Different Forms of Arthritis Assessed by Nuclear Magnetic Resonance Spectroscopy. Clin. Exp. Rheumatol. 2012, 30, $240-245$.

49. Maher, A.D.; Cloarec, O.; Patki, P.; Craggs, M.; Holmes, E.; Lindon, J.C.; Nicholson, J.K. Dynamic Biochemical Information Recovery in Spontaneous Human Seminal Fluid Reactions via 1H NMR Kinetic Statistical Total Correlation Spectroscopy. Anal. Chem. 2009, 81, 288-295. [CrossRef]

50. Le Gall, G.; Noor, S.O.; Ridgway, K.; Scovell, L.; Jamieson, C.; Johnson, I.T.; Colquhoun, I.J.; Kemsley, E.K.; Narbad, A. Metabolomics of Fecal Extracts Detects Altered Metabolic Activity of Gut Microbiota in Ulcerative Colitis and Irritable Bowel Syndrome. J. Proteome Res. 2011, 10, 4208-4218. [CrossRef]

51. Tiziani, S.; Kang, Y.; Choi, J.S.; Roberts, W.; Paternostro, G. Metabolomic High-Content Nuclear Magnetic Resonance-Based Drug Screening of a Library of Kinase Inhibitors. Nat. Commun. 2011, 2, 545. [CrossRef] 
52. D'Alessandro, G.; Quaglio, D.; Monaco, L.; Lauro, C.; Ghirga, F.; Ingallina, C.; De Martino, M.; Fucile, S.; Porzia, A.; Di Castro, M.A.; et al. 1H-NMR Metabolomics Reveals the Glabrescione B Exacerbation of Glycolytic Metabolism beside the Cell Growth Inhibitory Effect in Glioma. Cell Commun. Signal. 2019, 17, 108. [CrossRef]

53. Cheng, L.L.; Chang, I.W.; Louis, D.N.; Gonzalez, R.G. Correlation of High-Resolution Magic Angle Spinning Proton Magnetic Resonance Spectroscopy with Histopathology of Intact Human Brain Tumor Specimens. Cancer Res. 1998, 58, 1825-1832.

54. Tian, Y.; Xu, T.; Huang, J.; Zhang, L.; Xu, S.; Xiong, B.; Wang, Y.; Tang, H. Tissue Metabonomic Phenotyping for Diagnosis and Prognosis of Human Colorectal Cancer. Sci. Rep. 2016, 6, 20790. [CrossRef]

55. Bathen, T.F.; Sitter, B.; Sjøbakk, T.E.; Tessem, M.-B.; Gribbestad, I.S. Magnetic Resonance Metabolomics of Intact Tissue: A Biotechnological Tool in Cancer Diagnostics and Treatment Evaluation. Cancer Res. 2010, 70, 6692-6696. [CrossRef]

56. Cacciatore, S.; Hu, X.; Viertler, C.; Kap, M.; Bernhardt, G.A.; Mischinger, H.-J.; Riegman, P.; Zatloukal, K.; Luchinat, C.; Turano, P. Effects of Intra- and Post-Operative Ischemia on the Metabolic Profile of Clinical Liver Tissue Specimens Monitored by NMR. J. Proteome Res. 2013, 12, 5723-5729. [CrossRef] [PubMed]

57. Mckay, R.T. How the 1D-NOESY Suppresses Solvent Signal in Metabonomics NMR Spectroscopy: An Examination of the Pulse Sequence Components and Evolution. Concepts Magn. Reson. 2011, 38A, 197-220. [CrossRef]

58. Meiboom, S.; Gill, D. Modified Spin-Echo Method for Measuring Nuclear Relaxation Times. Rev. Sci. Instrum. 1958, 29 , 688-691. [CrossRef]

59. Wu, D.H.; Chen, A.D. Three-Dimensional Diffusion-Ordered NMR Spectroscopy: The Homonuclear COSY-DOSY Experiment. J. Magnen. Reson. A 1996, 123, 215-218. [CrossRef]

60. Wishart, D.S.; Tzur, D.; Knox, C.; Eisner, R.; Guo, A.C.; Young, N.; Cheng, D.; Jewell, K.; Arndt, D.; Sawhney, S.; et al. HMDB: The Human Metabolome Database. Nucleic. Acids Res. 2007, 35, D521-D526. [CrossRef] [PubMed]

61. Wishart, D.S.; Knox, C.; Guo, A.C.; Eisner, R.; Young, N.; Gautam, B.; Hau, D.D.; Psychogios, N.; Dong, E.; Bouatra, S.; et al. HMDB: A Knowledgebase for the Human Metabolome. Nucleic Acids Res. 2009, 37, D603-D610. [CrossRef] [PubMed]

62. Wishart, D.S.; Jewison, T.; Guo, A.C.; Wilson, M.; Knox, C.; Liu, Y.; Djoumbou, Y.; Mandal, R.; Aziat, F.; Dong, E.; et al. HMDB 3.0-The Human Metabolome Database in 2013. Nucleic Acids Res. 2013, 41, D801-D807. [CrossRef] [PubMed]

63. Dona, A.C.; Kyriakides, M.; Scott, F.; Shephard, E.A.; Varshavi, D.; Veselkov, K.; Everett, J.R. A Guide to the Identification of Metabolites in NMR-Based Metabonomics/Metabolomics Experiments. Comput. Struct. Biotechnol. J. 2016, 14, 135-153. [CrossRef]

64. Jiménez, B.; Holmes, E.; Heude, C.; Tolson, R.F.; Harvey, N.; Lodge, S.L.; Chetwynd, A.J.; Cannet, C.; Fang, F.; Pearce, J.T.M.; et al. Quantitative Lipoprotein Subclass and Low Molecular Weight Metabolite Analysis in Human Serum and Plasma by $1 \mathrm{H}$ NMR Spectroscopy in a Multilaboratory Trial. Anal. Chem. 2018, 90, 11962-11971. [CrossRef] [PubMed]

65. Laisupasin, P.; Thompat, W.; Sukarayodhin, S.; Sornprom, A.; Sudjaroen, Y. Comparison of Serum Lipid Profiles between Normal Controls and Breast Cancer Patients. J. Lab. Physicians 2013, 5, 38-41. [CrossRef]

66. Beckonert, O.; Keun, H.C.; Ebbels, T.M.D.; Bundy, J.; Holmes, E.; Lindon, J.C.; Nicholson, J.K. Metabolic Profiling, Metabolomic and Metabonomic Procedures for NMR Spectroscopy of Urine, Plasma, Serum and Tissue Extracts. Nat. Protoc. 2007, 2, $2692-2703$. [CrossRef]

67. Bernini, P.; Bertini, I.; Luchinat, C.; Nincheri, P.; Staderini, S.; Turano, P. Standard Operating Procedures for Pre-Analytical Handling of Blood and Urine for Metabolomic Studies and Biobanks. J. Biomol. Nmr. 2011, 49, 231-243. [CrossRef]

68. Ghini, V.; Quaglio, D.; Luchinat, C.; Turano, P. NMR for Sample Quality Assessment in Metabolomics. New Biotechnol. 2019, 52, 25-34. [CrossRef]

69. Emwas, A.-H.; Roy, R.; McKay, R.T.; Ryan, D.; Brennan, L.; Tenori, L.; Luchinat, C.; Gao, X.; Zeri, A.C.; Gowda, G.A.N.; et al. Recommendations and Standardization of Biomarker Quantification Using NMR-Based Metabolomics with Particular Focus on Urinary Analysis. J. Proteome Res. 2016, 15, 360-373. [CrossRef]

70. Salek, R.M.; Neumann, S.; Schober, D.; Hummel, J.; Billiau, K.; Kopka, J.; Correa, E.; Reijmers, T.; Rosato, A.; Tenori, L.; et al. COordination of Standards in MetabOlomicS (COSMOS): Facilitating Integrated Metabolomics Data Access. Metabolomics 2015, 11, 1587-1597. [CrossRef]

71. Borgan, E.; Sitter, B.; Lingjærde, O.C.; Johnsen, H.; Lundgren, S.; Bathen, T.F.; Sørlie, T.; Børresen-Dale, A.-L.; Gribbestad, I.S. Merging Transcriptomics and Metabolomics-Advances in Breast Cancer Profiling. BMC Cancer 2010, 10, 628. [CrossRef] [PubMed]

72. Li, M.; Song, Y.; Cho, N.; Chang, J.M.; Koo, H.R.; Yi, A.; Kim, H.; Park, S.; Moon, W.K. An HR-MAS MR Metabolomics Study on Breast Tissues Obtained with Core Needle Biopsy. PLoS ONE 2011, 6, e25563. [CrossRef]

73. Bathen, T.F.; Geurts, B.; Sitter, B.; Fjøsne, H.E.; Lundgren, S.; Buydens, L.M.; Gribbestad, I.S.; Postma, G.; Giskeødegård, G.F. Feasibility of MR Metabolomics for Immediate Analysis of Resection Margins during Breast Cancer Surgery. PLoS ONE 2013, 8 , e61578. [CrossRef] [PubMed]

74. Chae, E.Y.; Shin, H.J.; Kim, S.; Baek, H.-M.; Yoon, D.; Kim, S.; Shim, Y.E.; Kim, H.H.; Cha, J.H.; Choi, W.J.; et al. The Role of High-Resolution Magic Angle Spinning 1H Nuclear Magnetic Resonance Spectroscopy for Predicting the Invasive Component in Patients with Ductal Carcinoma In Situ Diagnosed on Preoperative Biopsy. PLoS ONE 2016, 11, e0161038. [CrossRef]

75. Park, V.Y.; Yoon, D.; Koo, J.S.; Kim, E.-K.; Kim, S.I.; Choi, J.S.; Park, S.; Park, H.S.; Kim, S.; Kim, M.J. Intratumoral Agreement of High-Resolution Magic Angle Spinning Magnetic Resonance Spectroscopic Profiles in the Metabolic Characterization of Breast Cancer. Medicine 2016, 95, e3398. [CrossRef] 
76. Gogiashvili, M.; Horsch, S.; Marchan, R.; Gianmoena, K.; Cadenas, C.; Tanner, B.; Naumann, S.; Ersova, D.; Lippek, F.; Rahnenführer, J.; et al. Impact of Intratumoral Heterogeneity of Breast Cancer Tissue on Quantitative Metabolomics Using High-Resolution Magic Angle Spinning 1 H NMR Spectroscopy. NMR Biomed. 2018, 31. [CrossRef] [PubMed]

77. Giskeødegård, G.F.; Grinde, M.T.; Sitter, B.; Axelson, D.E.; Lundgren, S.; Fjøsne, H.E.; Dahl, S.; Gribbestad, I.S.; Bathen, T.F. Multivariate Modeling and Prediction of Breast Cancer Prognostic Factors Using MR Metabolomics. J. Proteome Res. 2010, 9, 972-979. [CrossRef]

78. Choi, J.S.; Baek, H.-M.; Kim, S.; Kim, M.J.; Youk, J.H.; Moon, H.J.; Kim, E.-K.; Han, K.H.; Kim, D.-H.; Kim, S.I.; et al. HR-MAS MR Spectroscopy of Breast Cancer Tissue Obtained with Core Needle Biopsy: Correlation with Prognostic Factors. PLoS ONE 2012, 7, e51712. [CrossRef]

79. Cao, M.D.; Lamichhane, S.; Lundgren, S.; Bofin, A.; Fjøsne, H.; Giskeødegård, G.F.; Bathen, T.F. Metabolic Characterization of Triple Negative Breast Cancer. BMC Cancer 2014, 14, 941. [CrossRef]

80. Tayyari, F.; Gowda, G.A.N.; Olopade, O.F.; Berg, R.; Yang, H.H.; Lee, M.P.; Ngwa, W.F.; Mittal, S.K.; Raftery, D.; Mohammed, S.I. Metabolic Profiles of Triple-Negative and Luminal A Breast Cancer Subtypes in African-American Identify Key Metabolic Differences. Oncotarget 2018, 9, 11677-11690. [CrossRef]

81. Cheng, L.L.; Chang, I.W.; Smith, B.L.; Gonzalez, R.G. Evaluating Human Breast Ductal Carcinomas with High-Resolution Magic-Angle Spinning Proton Magnetic Resonance Spectroscopy. J. Magn. Reson. 1998, 135, 194-202. [CrossRef] [PubMed]

82. Bathen, T.F.; Jensen, L.R.; Sitter, B.; Fjösne, H.E.; Halgunset, J.; Axelson, D.E.; Gribbestad, I.S.; Lundgren, S. MR-Determined Metabolic Phenotype of Breast Cancer in Prediction of Lymphatic Spread, Grade, and Hormone Status. Breast Cancer Res. Treat. 2007, 104, 181-189. [CrossRef] [PubMed]

83. Sitter, B.; Lundgren, S.; Bathen, T.F.; Halgunset, J.; Fjosne, H.E.; Gribbestad, I.S. Comparison of HR MAS MR Spectroscopic Profiles of Breast Cancer Tissue with Clinical Parameters. NMR Biomed. 2006, 19, 30-40. [CrossRef] [PubMed]

84. Sitter, B.; Bathen, T.F.; Singstad, T.E.; Fjøsne, H.E.; Lundgren, S.; Halgunset, J.; Gribbestad, I.S. Quantification of Metabolites in Breast Cancer Patients with Different Clinical Prognosis Using HR MAS MR Spectroscopy. NMR Biomed. 2010, 23, 424-431. [CrossRef]

85. Choi, J.S.; Baek, H.-M.; Kim, S.; Kim, M.J.; Youk, J.H.; Moon, H.J.; Kim, E.-K.; Nam, Y.K. Magnetic Resonance Metabolic Profiling of Breast Cancer Tissue Obtained with Core Needle Biopsy for Predicting Pathologic Response to Neoadjuvant Chemotherapy. PLoS ONE 2013, 8. [CrossRef] [PubMed]

86. Euceda, L.R.; Haukaas, T.H.; Giskeødegård, G.F.; Vettukattil, M.R.; Engel, J.; Silwal-Pandit, L.; Lundgren, S.; Borgen, E.; Garred, Ø.; Postma, G.; et al. Evaluation of Metabolomic Changes during Neoadjuvant Chemotherapy Combined with Bevacizumab in Breast Cancer Using MR Spectroscopy. Metabolomics 2017, 13, 1-14. [CrossRef]

87. Cao, M.D.; Sitter, B.; Bathen, T.F.; Bofin, A.; Lønning, P.E.; Lundgren, S.; Gribbestad, I.S. Predicting Long-Term Survival and Treatment Response in Breast Cancer Patients Receiving Neoadjuvant Chemotherapy by MR Metabolic Profiling. NMR Biomed. 2012, 25, 369-378. [CrossRef]

88. Giskeødegård, G.F.; Lundgren, S.; Sitter, B.; Fjøsne, H.E.; Postma, G.; Buydens, L.M.C.; Gribbestad, I.S.; Bathen, T.F. Lactate and Glycine-Potential MR Biomarkers of Prognosis in Estrogen Receptor-Positive Breast Cancers. NMR Biomed. 2012, 25, 1271-1279. [CrossRef]

89. Cao, M.D.; Giskeødegård, G.F.; Bathen, T.F.; Sitter, B.; Bofin, A.; Lønning, P.E.; Lundgren, S.; Gribbestad, I.S. Prognostic Value of Metabolic Response in Breast Cancer Patients Receiving Neoadjuvant Chemotherapy. BMC Cancer 2012, 12, 39. [CrossRef]

90. Haukaas, T.H.; Euceda, L.R.; Giskeødegård, G.F.; Lamichhane, S.; Krohn, M.; Jernström, S.; Aure, M.R.; Lingjærde, O.C.; Schlichting, E.; Garred, Ø.; et al. Metabolic Clusters of Breast Cancer in Relation to Gene- and Protein Expression Subtypes. Cancer Metab. 2016, 4, 12. [CrossRef]

91. Yoon, H.; Yoon, D.; Yun, M.; Choi, J.S.; Park, V.Y.; Kim, E.-K.; Jeong, J.; Koo, J.S.; Yoon, J.H.; Moon, H.J.; et al. Metabolomics of Breast Cancer Using High-Resolution Magic Angle Spinning Magnetic Resonance Spectroscopy: Correlations with 18F-FDG Positron Emission Tomography-Computed Tomography, Dynamic Contrast-Enhanced and Diffusion-Weighted Imaging MRI. PLoS ONE 2016, 11, e0159949. [CrossRef] [PubMed]

92. Debik, J.; Euceda, L.R.; Lundgren, S.; von der Lippe Gythfeldt, H.; Garred, Ø.; Borgen, E.; Engebraaten, O.; Bathen, T.F.; Giskeødegård, G.F. Assessing Treatment Response and Prognosis by Serum and Tissue Metabolomics in Breast Cancer Patients. J. Proteome Res. 2019, 18, 3649-3660. [CrossRef]

93. Bro, R.; Kamstrup-Nielsen, M.H.; Engelsen, S.B.; Savorani, F.; Rasmussen, M.A.; Hansen, L.; Olsen, A.; Tjønneland, A.; Dragsted, L.O. Forecasting Individual Breast Cancer Risk Using Plasma Metabolomics and Biocontours. Metabolomics 2015, 11, 1376-1380. [CrossRef] [PubMed]

94. Cala, M.P.; Aldana, J.; Medina, J.; Sánchez, J.; Guio, J.; Wist, J.; Meesters, R.J.W. Multiplatform Plasma Metabolic and Lipid Fingerprinting of Breast Cancer: A Pilot Control-Case Study in Colombian Hispanic Women. PLoS ONE 2018, 13, e0190958. [CrossRef] [PubMed]

95. Lécuyer, L.; Victor Bala, A.; Deschasaux, M.; Bouchemal, N.; Nawfal Triba, M.; Vasson, M.-P.; Rossary, A.; Demidem, A.; Galan, P.; Hercberg, S.; et al. NMR Metabolomic Signatures Reveal Predictive Plasma Metabolites Associated with Long-Term Risk of Developing Breast Cancer. Int. J. Epidemiol. 2018, 484-494. [CrossRef] 
96. Louis, E.; Bervoets, L.; Reekmans, G.; De Jonge, E.; Mesotten, L.; Thomeer, M.; Adriaensens, P. Phenotyping Human Blood Plasma by 1H-NMR: A Robust Protocol Based on Metabolite Spiking and Its Evaluation in Breast Cancer. Metabolomics 2015, 11, 225-236. [CrossRef]

97. Richard, V.; Conotte, R.; Mayne, D.; Colet, J.-M. Does the 1H-NMR Plasma Metabolome Reflect the Host-Tumor Interactions in Human Breast Cancer? Oncotarget 2017, 8, 49915-49930. [CrossRef] [PubMed]

98. Suman, S.; Sharma, R.K.; Kumar, V.; Sinha, N.; Shukla, Y. Metabolic Fingerprinting in Breast Cancer Stages through 1H NMR Spectroscopy-Based Metabolomic Analysis of Plasma. J. Pharm. Biomed. Anal. 2018, 160, 38-45. [CrossRef] [PubMed]

99. Vignoli, A.; Muraro, E.; Miolo, G.; Tenori, L.; Turano, P.; Di Gregorio, E.; Steffan, A.; Luchinat, C.; Corona, G. Effect of Estrogen Receptor Status on Circulatory Immune and Metabolomics Profiles of HER2-Positive Breast Cancer Patients Enrolled for Neoadjuvant Targeted Chemotherapy. Cancers 2020, 12, 314. [CrossRef] [PubMed]

100. Jobard, E.; Dossus, L.; Baglietto, L.; Fornili, M.; Lécuyer, L.; Mancini, F.R.; Gunter, M.J.; Trédan, O.; Boutron-Ruault, M.-C.; Elena-Herrmann, B.; et al. Investigation of Circulating Metabolites Associated with Breast Cancer Risk by Untargeted Metabolomics: A Case-Control Study Nested within the French E3N Cohort. Br. J. Cancer 2021, 1-10. [CrossRef]

101. Keun, H.C.; Sidhu, J.; Pchejetski, D.; Lewis, J.S.; Marconell, H.; Patterson, M.; Bloom, S.R.; Amber, V.; Coombes, R.C.; Stebbing, J. Serum Molecular Signatures of Weight Change during Early Breast Cancer Chemotherapy. Clin. Cancer Res. 2009, 15, 6716-6723. [CrossRef] [PubMed]

102. Asiago, V.M.; Alvarado, L.Z.; Shanaiah, N.; Gowda, G.A.N.; Owusu-Sarfo, K.; Ballas, R.A.; Raftery, D. Early Detection of Recurrent Breast Cancer Using Metabolite Profiling. Cancer Res. 2010, 70, 8309-8318. [CrossRef] [PubMed]

103. Gu, H.; Pan, Z.; Xi, B.; Asiago, V.; Musselman, B.; Raftery, D. Principal Component Directed Partial Least Squares Analysis for Combining Nuclear Magnetic Resonance and Mass Spectrometry Data in Metabolomics: Application to the Detection of Breast Cancer. Anal. Chim. Acta 2011, 686, 57-63. [CrossRef]

104. Stebbing, J.; Sharma, A.; North, B.; Athersuch, T.J.; Zebrowski, A.; Pchejetski, D.; Coombes, R.C.; Nicholson, J.K.; Keun, H.C. A Metabolic Phenotyping Approach to Understanding Relationships between Metabolic Syndrome and Breast Tumour Responses to Chemotherapy. Ann. Oncol. 2012, 23, 860-866. [CrossRef] [PubMed]

105. Hart, C.D.; Vignoli, A.; Tenori, L.; Uy, G.L.; To, T.V.; Adebamowo, C.; Hossain, S.M.; Biganzoli, L.; Risi, E.; Love, R.R.; et al. Serum Metabolomic Profiles Identify ER-Positive Early Breast Cancer Patients at Increased Risk of Disease Recurrence in a Multicenter Population. Clin. Cancer Res. 2017, 23, 1422-1431. [CrossRef] [PubMed]

106. Jiang, L.; Lee, S.C.; Ng, T.C. Pharmacometabonomics Analysis Reveals Serum Formate and Acetate Potentially Associated with Varying Response to Gemcitabine-Carboplatin Chemotherapy in Metastatic Breast Cancer Patients. J. Proteome. Res. 2018, 17, 1248-1257. [CrossRef] [PubMed]

107. Jobard, E.; Trédan, O.; Bachelot, T.; Vigneron, A.M.; Aït-Oukhatar, C.M.; Arnedos, M.; Rios, M.; Bonneterre, J.; Diéras, V.; Jimenez, M.; et al. Longitudinal Serum Metabolomics Evaluation of Trastuzumab and Everolimus Combination as Pre-Operative Treatment for HER-2 Positive Breast Cancer Patients. Oncotarget 2017, 8, 83570-83584. [CrossRef]

108. Jobard, E.; Pontoizeau, C.; Blaise, B.J.; Bachelot, T.; Elena-Herrmann, B.; Trédan, O. A Serum Nuclear Magnetic Resonance-Based Metabolomic Signature of Advanced Metastatic Human Breast Cancer. Cancer Lett. 2014, 343, 33-41. [CrossRef]

109. McCartney, A.; Vignoli, A.; Tenori, L.; Fornier, M.; Rossi, L.; Risi, E.; Luchinat, C.; Biganzoli, L.; Di Leo, A. Metabolomic Analysis of Serum May Refine 21-Gene Expression Assay Risk Recurrence Stratification. NPJ Breast Cancer 2019, 5, 26. [CrossRef]

110. Oakman, C.; Tenori, L.; Claudino, W.M.; Cappadona, S.; Nepi, S.; Battaglia, A.; Bernini, P.; Zafarana, E.; Saccenti, E.; Fornier, M.; et al. Identification of a Serum-Detectable Metabolomic Fingerprint Potentially Correlated with the Presence of Micrometastatic Disease in Early Breast Cancer Patients at Varying Risks of Disease Relapse by Traditional Prognostic Methods. Ann. Oncol. 2011, 22, 1295-1301. [CrossRef]

111. Singh, A.; Sharma, R.K.; Chagtoo, M.; Agarwal, G.; George, N.; Sinha, N.; Godbole, M.M. 1H NMR Metabolomics Reveals Association of High Expression of Inositol 1, 4, 5 Trisphosphate Receptor and Metabolites in Breast Cancer Patients. PLoS ONE 2017, 12, e169330. [CrossRef]

112. Tenori, L.; Oakman, C.; Claudino, W.M.; Bernini, P.; Cappadona, S.; Nepi, S.; Biganzoli, L.; Arbushites, M.C.; Luchinat, C.; Bertini, I.; et al. Exploration of Serum Metabolomic Profiles and Outcomes in Women with Metastatic Breast Cancer: A Pilot Study. Mol. Oncol. 2012, 6, 437-444. [CrossRef] [PubMed]

113. Tenori, L.; Oakman, C.; Morris, P.G.; Gralka, E.; Turner, N.; Cappadona, S.; Fornier, M.; Hudis, C.; Norton, L.; Luchinat, C.; et al. Serum Metabolomic Profiles Evaluated after Surgery May Identify Patients with Oestrogen Receptor Negative Early Breast Cancer at Increased Risk of Disease Recurrence. Results from a Retrospective Study. Mol. Oncol. 2015, 9, 128-139. [CrossRef]

114. Wei, S.; Liu, L.; Zhang, J.; Bowers, J.; Gowda, G.A.N.; Seeger, H.; Fehm, T.; Neubauer, H.J.; Vogel, U.; Clare, S.E.; et al. Metabolomics Approach for Predicting Response to Neoadjuvant Chemotherapy for Breast Cancer. Mol. Oncol. 2013, 7, $297-307$. [CrossRef]

115. Wojtowicz, W.; Wróbel, A.; Pyziak, K.; Tarkowski, R.; Balcerzak, A.; Bębenek, M.; Młynarz, P. Evaluation of MDA-MB-468 Cell Culture Media Analysis in Predicting Triple-Negative Breast Cancer Patient Sera Metabolic Profiles. Metabolites 2020, $10,173$. [CrossRef] [PubMed]

116. Flote, V.G.; Vettukattil, R.; Bathen, T.F.; Egeland, T.; McTiernan, A.; Frydenberg, H.; Husøy, A.; Finstad, S.E.; Lømo, J.; Garred, Ø.; et al. Lipoprotein Subfractions by Nuclear Magnetic Resonance Are Associated with Tumor Characteristics in Breast Cancer. Lipids Health Dis. 2016, 15, 56. [CrossRef] [PubMed] 
117. Madssen, T.S.; Thune, I.; Flote, V.G.; Lundgren, S.; Bertheussen, G.F.; Frydenberg, H.; Wist, E.; Schlichting, E.; Schäfer, H.; Fjøsne, H.E.; et al. Metabolite and Lipoprotein Responses and Prediction of Weight Gain during Breast Cancer Treatment. Br. J. Cancer 2018, 119, 1144-1154. [CrossRef]

118. Zhou, J.; Wang, Y.; Zhang, X. Metabonomics Studies on Serum and Urine of Patients with Breast Cancer Using 1 H-NMR Spectroscopy. Oncotarget 2017, 5. [CrossRef]

119. Men, Y.; Li, L.; Zhang, F.; Kong, X.; Zhang, W.; Hao, C.; Wang, G. Evaluation of Heavy Metals and Metabolites in the Urine of Patients with Breast Cancer. Oncol. Lett. 2020, 19, 1331-1337. [CrossRef]

120. Silva, C.L.; Olival, A.; Perestrelo, R.; Silva, P.; Tomás, H.; Câmara, J.S. Untargeted Urinary 1H NMR-Based Metabolomic Pattern as a Potential Platform in Breast Cancer Detection. Metabolites 2019, 9, 269. [CrossRef]

121. Slupsky, C.M.; Steed, H.; Wells, T.; Dabbs, K.; Schepansky, A.; Capstick, V.; Faught, W.; Sawyer, M.B. Urine Metabolite Analysis Offers Potential Early Diagnosis of Ovarian and Breast Cancers. Clin. Cancer Res. 2010; 16, 5835-5841. [CrossRef]

122. Vander Heiden, M.G.; Cantley, L.C.; Thompson, C.B. Understanding the Warburg Effect: The Metabolic Requirements of Cell Proliferation. Science 2009, 324, 1029-1033. [CrossRef]

123. McCartney, A.; Vignoli, A.; Biganzoli, L.; Love, R.; Tenori, L.; Luchinat, C.; Di Leo, A. Metabolomics in Breast Cancer: A Decade in Review. Cancer Treat. Rev. 2018, 67, 88-96. [CrossRef]

124. McCartney, A.; Vignoli, A.; Hart, C.; Tenori, L.; Luchinat, C.; Biganzoli, L.; Di Leo, A. De-Escalating and Escalating Treatment beyond Endocrine Therapy in Patients with Luminal Breast Cancer. Breast 2017, 34, S13-S18. [CrossRef]

125. Kaddurah-Daouk, R.; Weinshilboum, R.M. Pharmacometabolomics Research Network Pharmacometabolomics: Implications for Clinical Pharmacology and Systems Pharmacology. Clin. Pharm. 2014, 95, 154-167. [CrossRef]

126. Thompson, A.M.; Moulder-Thompson, S.L. Neoadjuvant Treatment of Breast Cancer. Ann. Oncol. 2012, 23, x231-x236. [CrossRef] [PubMed]

127. Monsonis Centelles, S.; Hoefsloot, H.C.J.; Khakimov, B.; Ebrahimi, P.; Lind, M.V.; Kristensen, M.; de Roo, N.; Jacobs, D.M.; van Duynhoven, J.; Cannet, C.; et al. Toward Reliable Lipoprotein Particle Predictions from NMR Spectra of Human Blood: An Interlaboratory Ring Test. Anal. Chem. 2017, 89, 8004-8012. [CrossRef] [PubMed]

128. Ferlay, J.; Colombet, M.; Soerjomataram, I.; Mathers, C.; Parkin, D.M.; Piñeros, M.; Znaor, A.; Bray, F. Estimating the Global Cancer Incidence and Mortality in 2018: GLOBOCAN Sources and Methods. Int. J. Cancer 2019, 144, 1941-1953. [CrossRef]

129. Duffy, M.J. Serum Tumor Markers in Breast Cancer: Are They of Clinical Value? Clin. Chem. 2006, 52, 345-351. [CrossRef]

130. Lehman, C.D.; Arao, R.F.; Sprague, B.L.; Lee, J.M.; Buist, D.S.M.; Kerlikowske, K.; Henderson, L.M.; Onega, T.; Tosteson, A.N.A.; Rauscher, G.H.; et al. National Performance Benchmarks for Modern Screening Digital Mammography: Update from the Breast Cancer Surveillance Consortium. Radiology 2017, 283, 49-58. [CrossRef]

131. Jové, M.; Collado, R.; Quiles, J.L.; Ramírez-Tortosa, M.-C.; Sol, J.; Ruiz-Sanjuan, M.; Fernandez, M.; de la Torre Cabrera, C.; Ramírez-Tortosa, C.; Granados-Principal, S.; et al. A Plasma Metabolomic Signature Discloses Human Breast Cancer. Oncotarget 2017, 8, 19522-19533. [CrossRef] [PubMed]

132. Wang, Q.; Sun, T.; Cao, Y.; Gao, P.; Dong, J.; Fang, Y.; Fang, Z.; Sun, X.; Zhu, Z. A Dried Blood Spot Mass Spectrometry Metabolomic Approach for Rapid Breast Cancer Detection. Onco Targets 2016, 9, 1389-1398. [CrossRef]

133. Yang, L.; Wang, Y.; Cai, H.; Wang, S.; Shen, Y.; Ke, C. Application of Metabolomics in the Diagnosis of Breast Cancer: A Systematic Review. J. Cancer 2020, 11, 2540-2551. [CrossRef]

134. Perou, C.M.; Sørlie, T.; Eisen, M.B.; van de Rijn, M.; Jeffrey, S.S.; Rees, C.A.; Pollack, J.R.; Ross, D.T.; Johnsen, H.; Akslen, L.A.; et al. Molecular Portraits of Human Breast Tumours. Nature 2000, 406, 747-752. [CrossRef]

135. Cancer Genome Atlas Network. Comprehensive Molecular Portraits of Human Breast Tumours. Nature 2012, 490, 61-70. [CrossRef]

136. Cortazar, P.; Zhang, L.; Untch, M.; Mehta, K.; Costantino, J.P.; Wolmark, N.; Bonnefoi, H.; Cameron, D.; Gianni, L.; Valagussa, P.; et al. Pathological Complete Response and Long-Term Clinical Benefit in Breast Cancer: The CTNeoBC Pooled Analysis. Lancet 2014, 384, 164-172. [CrossRef]

137. Miolo, G.; Muraro, E.; Caruso, D.; Crivellari, D.; Ash, A.; Scalone, S.; Lombardi, D.; Rizzolio, F.; Giordano, A.; Corona, G. Pharmacometabolomics Study Identifies Circulating Spermidine and Tryptophan as Potential Biomarkers Associated with the Complete Pathological Response to Trastuzumab-Paclitaxel Neoadjuvant Therapy in HER-2 Positive Breast Cancer. Oncotarget 2016, 7, 39809-39822. [CrossRef]

138. Blok, E.J.; Bastiaannet, E.; van den Hout, W.B.; Liefers, G.J.; Smit, V.T.H.B.M.; Kroep, J.R.; van de Velde, C.J.H. Systematic Review of the Clinical and Economic Value of Gene Expression Profiles for Invasive Early Breast Cancer Available in Europe. Cancer Treat. Rev. 2018, 62, 74-90. [CrossRef] [PubMed]

139. Nannini, G.; Meoni, G.; Amedei, A.; Tenori, L. Metabolomics Profile in Gastrointestinal Cancers: Update and Future Perspectives. World J. Gastroenterol. 2020, 26, 2514-2532. [CrossRef]

140. PD CEN/TS 16945:2016. PD CEN/TS 16945:201. Molecular in Vitro Diagnostic Examinations. Specifications for Pre-Examination Processes for Metabolomics in Urine, Venous Blood Serum and Plasma; ISO: Geneva, Switzerland, 2016.

141. Trivedi, D.K.; Hollywood, K.A.; Goodacre, R. Metabolomics for the Masses: The Future of Metabolomics in a Personalized World. New Horiz. Transl. Med. 2017, 3, 294-305. [CrossRef] 